\title{
Out of the Gray: The Impact of Provincial Institutions on Business Formalization in Vietnam
}

\author{
Edmund Malesky and Markus Taussig
}

\begin{abstract}
Scholars have long argued that institutional context significantly influences business strategy and economic performance. Research on the relationship between institutions and business strategy, however, has overwhelmingly focused on the decisions of larger, established corporations, mostly neglecting the strategic thinking of smaller, more entrepreneurial ventures. This article seeks to correct this bias by focusing the analysis directly on the critical decision of small-scale entrepreneurs to move from the informal and largely unregulated sector into operation as formal companies. Using a unique dataset and ranking of provincial governance institutions from Vietnam, the authors show that improvements in institutions make firms more likely to choose the formal sector from the start and, for those who do not, to spend less time in the informal sector. The study also finds that property rights have a more salient impact on formalization than other types of institutions.
\end{abstract}

KeYwORDS: formalization, property rights, Vietnam, land title, governance, institutions, provincial competitiveness index, PCI, institutions, economic growth

cholars have long argued that institutional context significantly influences business strategy, as governance influences the propensity of firms to invest and their ability to grow (Porter 1980; DiMaggio and Powell 1991; North 1991; Weingast 1993; Knack and Keefer 1995; Grief 2006). Research on the interaction between institutions and business strategy, however, has overwhelmingly focused on the decisions of larger, established corporations rather than smaller, more entrepreneurial ventures. This oversight is significant because, given the higher mortality they face, early-stage firms are much more averse to uncertainty than their more mature counterparts (Aldrich and Fiol 1994; Santos and Eisenhardt 2006). As a result, there is a signifi- 
cant need for further research to understand how institutions influence new firms and what role they play in driving aggregate economic growth and employment creation.

In this article, we consider the impact of the quality of governance on an especially fundamental strategic decision faced by every nascent entrepreneur: the decision to stay in the informal sector or to submit to formal government regulation. In practice, formalization means registering as a company and thereby acknowledging the size and scope of business operations to tax officials and regulators. More conceptually, we analyze how the quality of local institutions influences the decision to transition from avoiding government attention to accepting it.

Better understanding the microlevel dynamic of this entrepreneurial decision is of great importance to our understanding of both politics and economic growth. When entrepreneurs choose to stay in the informal economy, governments lose tax revenues, the public faces danger from ineffective health and environmental regulation, and a vicious circle ensues that undermines rule of law. This vicious circle involves poor governance, which leads to greater informality, which leads in turn to even worse governance as policymakers lose out on information and other resources needed to properly regulate competition and protect the public. Indeed, the problem may even affect a country's economic growth, as informal entrepreneurs self-select into lower-growth trajectories. Simeon Djankov (2008), for example, argues that the movement of firms from the informal economy into the formal economy is the most important benefit from improving governance and institutions.

The so-called underground economy is substantial even in advanced economies like Singapore and South Korea (Loayza, Oviedo, and Serven 2005) but is even more germane in developing countries, where the informal economy often totals as much as half the value of official GDP (Loayza, Oviedo, and Serven 2005; Schneider 2005). The World Bank suggests that more than 30 percent of total output in developing countries lies outside the realm of government regulation and that this share may actually be growing (Kenyon 2007). Cross-national research designs have consistently found that weak institutions and governance are associated with lower shares of business activity occurring within the formal, government-regulated economy (Frye and Shleifer 1997; Johnson, Shleifer, and Kaufmann 1997; La Porta et al. 1999; Johnson et al. 2000; Friedman et al. 2000; Ihrig and Moe 2004; Antunes and Cavalcanti 2007; Djankov et al. 2008). These findings are consistent with theoretical work suggesting that the probability of 
"going formal" increases with prospects for future profitability (Bennett and Estrin 2007).

While the cross-national work analyzing the relationship between institutions and formalization is illustrative, its conception of both institutions and causality is expansive. In general, there has been a failure to disentangle an extremely broad spectrum of highly correlated institutional factors that affect the environment facing business. This lack of precision in identifying the mechanics of the relationship between institutions, business strategies, and growth has naturally led to significant criticism from political scientists and global management scholars (Kurtz and Schrank 2007; Ghemawat 2007).

This article tests the hypothesis that higher-quality governance increases the probability that individual entrepreneurs will transition from the informal economy to the formal economy (an action henceforth referred to as "formalization"). We test this hypothesis on a unique firm-level dataset covering all sixty-four provinces in nominally communist, but economically liberalizing and rapidly growing, Vietnam. The subnational design allows us to hold constant cultural and historical factors that plague cross-national analyses (King et al. 2003), while focusing our attention on the quality of specific institutions, which varies considerably among subnational units in Vietnam.

As noted earlier, research on formalization around the world has been bedeviled by the fact that it is usually not possible to access information on completely informal firms. This is true in Vietnam as well. But it is possible to use survey data to place firms along a spectrum of formality. Near the informal end of this spectrum, most small businesses are registered at the local level as household businesses but face substantially less (and more subjective) regulation than those firms registered as companies. Toward the more formal end of the spectrum, even fully registered companies are likely to engage in deception and negotiation in their dealings with tax and other regulatory authorities. Because of this complex reality, we operationalize formalization as movement by an entrepreneur from the relatively informal household business sector to the relatively formal company sector. Even though our quantitative analysis measures a dichotomous choice, our conceptualization of formalization recognizes a more complex process.

Our results show that entrepreneurs in Vietnamese provinces with higher-quality governance are significantly more likely to submit to more extensive government regulation from the start of their operations. Further confirming our key hypothesis, we find that entrepreneurs who 
initially select into the informal sector spend relatively less time there when local institutions are better.

We then address the serious issues of endogeneity endemic to research on institutions and business decisionmaking by adopting a twostage, instrumental variable approach. Our strategy takes advantage of Vietnam's war legacy to identify an exogenous determinant of the quality of governance. The findings of these models strengthen our argument that the causal direction runs from institutions to formalization.

Finally, after demonstrating the strength of our aggregate measure of governance, we disaggregate the composite index into its subcomponents to see what types of institutions are the primary drivers of business formalization. This question, of course, is of critical importance to policymakers in developing countries. Scholars have highlighted property rights (North 1991; North and Weingast 1989; Grief 2006), contract enforcement institutions (Coase 1937; Laeven and Woodruff 2007), and regulatory institutions (Djankov et al. 2002). Some effort has been made to disaggregate these effects (Acemoglu and Johnson 2005), but the analysis has relied on cross-national regression, where the dependent variable was GDP and not firm-level decisions. We find preliminary microlevel evidence that the key types of institutions driving formalization are property rights protection and confidence in local legal institutions.

Our study offers noteworthy contributions to three distinct literatures. First, we provide empirical evidence in support of the optimistic perspective, made famous by Hernando De Soto (1989), that informal enterprises represent a latent and underappreciated source of potential economic growth in developing countries. Our findings complement previous work (Di Tella, Galiani, and Schargrodsky 2007; Galiani and Schargrodsky 2007; Field 2007) by demonstrating that policy initiatives aimed at clarifying property rights are a crucial, relatively cheap, and expeditious way to unlock this potential.

The second contribution of this article is to the rapidly growing entrepreneurship literature. Our study represents a relatively rare large- $\mathrm{N}$ empirical test of how particular environmental factors influence a clearly defined strategic decision faced by all entrepreneurial ventures. Given that formality is far more conducive to firm growth, the study's findings demonstrate a way in which external conditions shape the strategic orientation of entrepreneurs (Ardagna and Lusardi 2008). In particular, they indicate that better institutions increase the probability of subsistenceoriented entrepreneurs turning into growth-oriented entrepreneurs.

Finally, we address the extensive literature on institutions and growth. Particularly germane is the recent debate in the pages of Jour- 
nal of Politics on the relationship between cross-national measures of governance and economic growth. Marcus Kurtz and Andrew Schrank (2007) argue that both the theoretical foundations and empirical analysis of the relationship are weak, while Daniel Kaufmann, Aart Kraay, and Massimo Mastruzzi (2007), architects of the most commonly cited measure of governance, defend their index and analyses of the impact of governance on growth.

Our research design allows us to address many of the criticisms leveled against the governance-growth research program. First, as discussed earlier, we bypass the large problems of unobserved heterogeneity in cross-national designs by focusing on units of analysis where most confounding historical and cultural factors can be held constant. Second, our decision-level analysis tests the causal logic directly and not through macrolevel proxies for entrepreneurial decisions such as GDP growth or even aggregate investment. This allows a clearer diagnosis of the mechanism by which institutions foster better economic outcomes. Third, our research design is not vulnerable to the charge of "halo effects" that dogs much of the relevant work in which firm-level surveys are used-the charge that survey respondents may be more likely to assign higher governance scores when located in areas characterized by recent economic growth (Seligson 2006). Kurtz and Schrank (2007) demonstrate the power of controlling for recent growth by showing that the significance of governance variables disappears in cross-national regressions. We avoid the halo effect because our dependent variable is the individual entrepreneur's one-time decision to formalize operations, not an aggregate measure of previous formalization that could color respondents' views.

The article is organized as follows. In the first section, we discuss the specific case of Vietnam. Second, we introduce our data source and key variables. In the next two sections, we lay out our results and demonstrate our identification strategy for assessing the causal argument. In the final section, we disaggregate governance institutions and demonstrate which particular components of our aggregate governance measure drive formalization decisions.

\section{The Case of Vietnam}

Private business has a long history in Vietnam, despite the extended rule of the country's Communist party. ${ }^{1}$ Upon coming to power in 1945, Ho Chi Minh's government made a concerted effort to promote 
local private business vis-à-vis dominant French business interests. Indeed, even in the headiest days of central planning, when all forms of private business were formally illegal, the majority of Vietnamese worked in the informal private sector (Abrami and Henaff 2004). Throughout, entrepreneurs remained crucial to the functioning of the economy and to social welfare, filling in whenever and wherever the clumsy government system failed.

The pragmatic practice of certain local authorities' turning a blind eye to illegal, but socially beneficial, entrepreneurial activity during the central planning period has been referred to as "fence breaking" (Fforde and de Vylder 1996). Such behavior characterized both Communist North Vietnam and subsequently unified, prereform Vietnam. Illegally operating entrepreneurs, however, were always at the mercy of political campaigns, serving as easy targets of blame in periods of inflation and unemployment. This history and the continued lack of transparency and consistency of government policy and policy implementation still have an impact even today on entrepreneurs' attitudes toward more open approaches to doing business. This is reflected, for example, in the continued value placed on political connections as business resources-even in the face of evidence that connected entrepreneurs do not actually perform any better than their less connected counterparts (Malesky and Taussig 2008).

These findings on fence breaking are not meant to minimize the significance of the launch in 1986 of doi moi (renovation) reforms for private business. One of the first economic reform moves was the legalization of private sector activity and soon thereafter the establishment of a registration process for household enterprises. ${ }^{2}$ This reform happened fully two years before the establishment of a legal framework for private companies. ${ }^{3}$ Two decades later, the household sector remains the leading employer in not only agriculture, but also industry and services. Household enterprises played the particularly important role of absorbing a large share of the many workers cut loose from the state sector and military in the early years of the reform period and continue to serve as the country's de facto primary welfare safety net.

While there are many data problems in identifying precisely the number of household businesses, it is clear that they have grown rapidly. In a recent comprehensive survey of household activities, Vietnam's General Statistics Office (GSO) identified 3.7 million household businesses. This compares to about 1 million in 1992 and around 2.5 million in 2002. Most operations employed only one or two workers, with approximately 80 percent of these workers not receiving a regular 
salary (e.g., family members) (VCCI 2008). While sources differ, household businesses appear to account for approximately 15 percent of GDP (Vietbao.vn 2007). This is about two times the share of registered sole proprietorships-the smallest, and thus most comparable, form of private company (Vijverberg 2006).

A domestic company sector also emerged in the early doi moi era following introduction of the country's first enterprise laws in 1990 and 1991, but growth stalled in the late 1990s at about 7-8 percent of GDP. Following a couple of years of slowed growth that coincided with the broader East Asian economic crisis, Vietnam introduced an updated enterprise law in January 2000 that dramatically reduced entry barriers (including time costs and requisite licenses) to setting up a company. ${ }^{4}$

The new enterprise law (henceforth "the Enterprise Law") mandated a simplified registration process that essentially eliminated differences in entry costs across provinces. Table 1 shows dramatic evidence of the reduction in registration times. In 1998, the median firm waited nearly a month to fulfill registration procedures. By 2000, waiting periods had been halved to fifteen days. This leveling of the playing field was achieved through aggressive implementation of the law, which included public castigation of particular agencies and officials seen to not be on board (Nguyen et al. 2004).

By the end of 2006, after seven consecutive years of increased annual registration totals, there were over 120,000 registered private companies operating in Vietnam-nearly six times the number in operation before the Enterprise Law came into effect in January 2000. A 2005 report by the Vietnam Chamber of Commerce and Industry suggested that a significant share of the increased registrations were, in fact, the formalization of firms formerly operating as household businesses (Taussig and Pham 2004). Table 1 further illustrates that companies that registered in 2000 or later were significantly less likely to have previously operated as household enterprises, and those that had been household enterprises spent significantly less time in the informal sector after the law. This is particularly true for firms in business services and higher-technology industries.

As noted earlier, our concept of formalization does not involve a move from completely informal to completely formal, as it would be misleading to refer to household businesses in Vietnam as fully informal. Indeed, if the term informal is meant to mean government authorities do not know about the existence of a particular business, Vietnam is likely to have very few informal businesses at all. It is true that, in the earlier-mentioned comprehensive GSO survey, only about a third of 


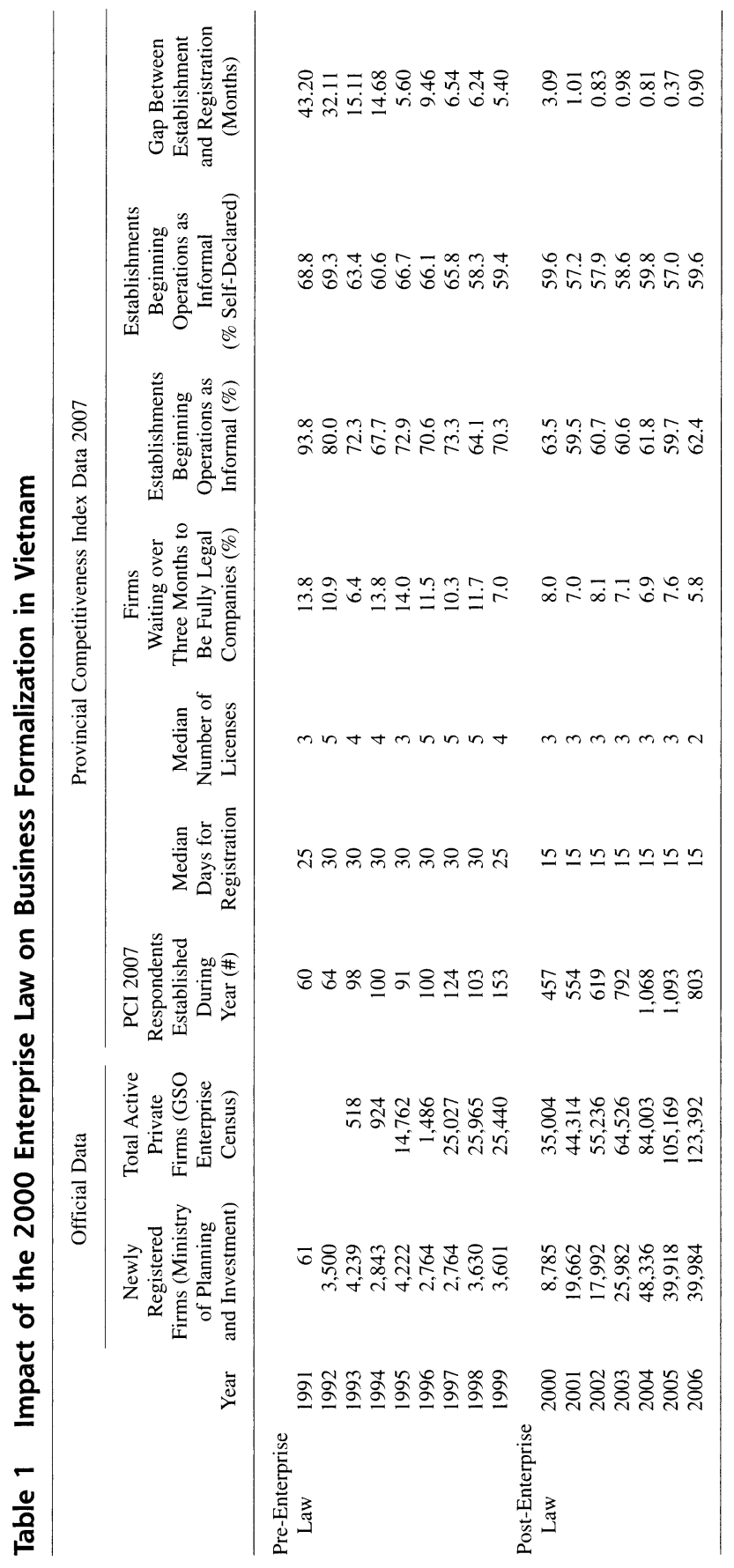


household businesses had both registered with district authorities and fulfilled all obligations to pay an annual license fee and taxes. Given Vietnam's administrative system and the fact that these firms were indeed captured by the GSO survey, however, it is highly unlikely that even the subset that have not registered are operating entirely under the radar of officials at even the subdistrict (i.e., ward) level. As a result, local officials can be seen as complicit in allowing small-scale enterprises to opt out of registering with responsible higher-level authorities.

The basic argument behind this conception of formalization is that, in Vietnam, companies face a relatively more rigorous and transparent regulatory system than do household businesses. Officially, regulatory responsibilities for household businesses (ho kinh doanh ca the) and companies (doanh nghiep) are divided across two distinct administrative levels. Generally speaking, household businesses are overseen by district-level authorities, while companies are the responsibility of provincial-level authorities. An exception is Vietnam's largest cities, Ho Chi Minh City and Hanoi, where oversight of smaller companies is also delegated to the district level.

As such, businesses that are of similar size and that undertake similar activities but are not of the same legal form are covered by different regulations, for example, with regard to environmental standards, fire prevention, and health insurance for workers (Vietbao.vn 2006). At the same time, similar-sized household businesses can be treated very differently depending on their location and the attitude of local authorities. In general, the regulatory framework that covers the activities of household businesses is less comprehensive, less transparent, and less strictly implemented across localities than the one that covers companies. With specific regard to differences across localities, for example, there is extensive anecdotal evidence that a 2004 decree requiring all businesses with more than ten workers or more than one business location to register as companies, not household businesses, has not been enforced in certain parts of the country (Taussig and Pham 2004).

\section{The Role of Provincial Government in Vietnam}

There are two important elements to note about the formalization decision. First, registration at the provincial level entails an entirely different legal regime than district-level oversight. The relative difference in the quality of district versus provincial governance is not of concern in this decision: officials are enforcing different rules and their activities are not directly comparable. Second, district officials are subordinate to 
provincial leaders. Their appointments, budgets, and career prospects are all determined by provincial-level benefactors. Although there is some variance in the level of authority that has been delegated to district officials by provinces, the quality of district-level governance is generally a reflection of provincial decisionmakers. As a result, the appropriate level of analysis of institutions is the provincial level rather than the district-province dyad level.

In this article, we test the hypothesis that the quality of provincial governance plays an important role in the formalization decision. It is true that there are clear business benefits to formalization in Vietnam. Firms are better able to expand their operations through easier access to export licenses, customs certificates, and opportunities to bid on lucrative government contracts. Companies also have the legal right to open up branches and operate beyond the bounds of their own district. In the case of more sophisticated corporate governance structures, such as shareholding companies, formalization also provides the additional protection of limited liability and allows firms to take on additional equity investors.

Formalization, however, also entails costs that must be weighed against these benefits. First, firms must absorb the direct costs of formalization in terms of fees for licenses and waiting periods to legally start operations. Second, formalization entails better documentation of the true extent of firms' sales and profitability. More rigorous accounting procedures can entail some learning costs and even necessitate employment of a certified accountant.

These direct costs, while important, can be dwarfed by the indirect costs of transparency. Provincial bureaucrats are now aware of the size of a firm's operations. In poorly governed Vietnamese provinces, characterized by corruption and inadequate property rights protections, this knowledge can be easily exploited by officials. Entrepreneurs with established arrangements with district-level officials may fear that opening themselves up to regulation by provincial government will only exacerbate the frequency and size of bribe payments. Thus, the quality of governance matters a great deal for the cost-benefit calculus of an entrepreneur considering formalization. The more restrained the "grabbing hand" of provincial bureaucrats is, the more incentive a firm has to formalize. In contrast, when corruption is high and property rights are poorly protected, entrepreneurs may feel that they are better off remaining in the gray economy.

Previous analyses have demonstrated wide variation in economic governance among Vietnamese provinces and also have shown that this 
variance is critical in explaining key indicators of economic performance, such as growth in the number of private companies, firm investment (Tran, Grafton, and Kompas 2008), foreign direct investment (Vu, Le, and Vo 2007; Riehl 2008; Malesky 2008), and economic growth (Malesky 2007). All of these analyses rely on an annual ranking of economic governance in Vietnam's sixty-four provinces by the Vietnam Chamber of Commerce and Industry and Vietnam Competitiveness Initiative called the Provincial Competitiveness Index (PCI). At its most basic level, the PCI is the collective voice of about 7,000 domestic private firms. ${ }^{5}$ Private entrepreneurs' opinions regarding economic governance in their provinces are collected in a twenty-page survey. Responses are paired with relevant, published economic data to address perception biases and are combined to create provincial-level scores.

The final outcome is a composite index ranking Vietnam's sixty-four provinces according to the following ten dimensions of governance:

1. Entry costs: A measure of the time it takes a firm to register, the time to receive all the necessary licenses needed to start a business, the number of licenses required to operate a business, and the perceived degree of difficulty to obtain all licenses/permits.

2. Land access and security of tenure: A measure combining two dimensions of the land problems confronting entrepreneurs-how easy it is to access land and the security of tenure once land is acquired.

3. Transparency and access to information: A measure of whether firms have access to the proper planning and legal documents necessary to run their businesses, whether those documents are equitably available, whether new policies and laws are communicated to firms and predictably implemented, and the business utility of the provincial Web page.

4. Time costs of regulatory compliance: A measure of how much time firms waste on bureaucratic compliance after registration, as well as how often and for how long firms must shut their operations down for inspections by local regulatory agencies.

5. Informal charges: A measure of how much firms pay in informal charges, how much of an obstacle those extra fees pose for their business operations, whether payment of those extra fees results in expected results or "services," and whether provincial officials use compliance with local regulations to extract rents.

6. Competition environment and state-owned enterprise (SOE) bias: A measure focusing on the perceived bias of provincial govern- 
ments toward SOEs, equitized firms, and other provincial champions in terms of incentives, policy, and access to capital.

7. Proactivity of provincial leadership: A measure of the creativity and cleverness of provinces in implementing central policy, designing their own initiatives for private sector development, and working within sometimes unclear national regulatory frameworks to assist and interpret in favor of local private firms.

8. Business development services (BDS): A measure of provincial services for private sector trade promotion, provision of regulatory information to firms, business partner matchmaking, provision of industrial zones or industrial clusters, and technological services for firms.

9. Labor and training: A measure of the efforts by provincial authorities to promote vocational training and skills development for local industries and to assist in the placement of local labor with provincial businesses.

10. Confidence in legal institutions: A measure of the private sector's confidence in provincial legal institutions; whether firms regard provincial legal institutions as an effective vehicle for dispute resolution or as an avenue for lodging appeals against corrupt official behavior. ${ }^{6}$

More detail on the specific survey questions and indicators used in the index construction is available in the annual reports. ${ }^{7}$ Table 2 shows that subindexes in the index are all positively correlated; however, only four of the subindex dyads have bivariate correlations greater than 60 . Table 3 takes the analysis of underlying correlations a bit further, through the use of factor analysis, to assess the latent variables that undergird the correlations between subindexes.

Three significant factors are revealed to be responsible for about 64 percent of the cumulative variance between subindexes. The first factor contains the three most strongly correlated subindexes and two others that are generally concerned with postregistration policies and regulation in the provincial business environment. Transparency, labor, $B D S$, proactivity, and time costs all involve the local-level policy initiatives or decisions to implement those policy choices. The second factor is clearly related to a general conception of property rights, consisting of the ability to access and the security of business premises (land access), the faith firms have that provincial courts will enforce contracts (confidence in legal institutions), and firm perceptions of the corruption of provincial officials (informal charges). These subindexes have less to do with implementation of policies and more to do with the formal restraints placed on the grabbing hand of bureaucrats. Good 


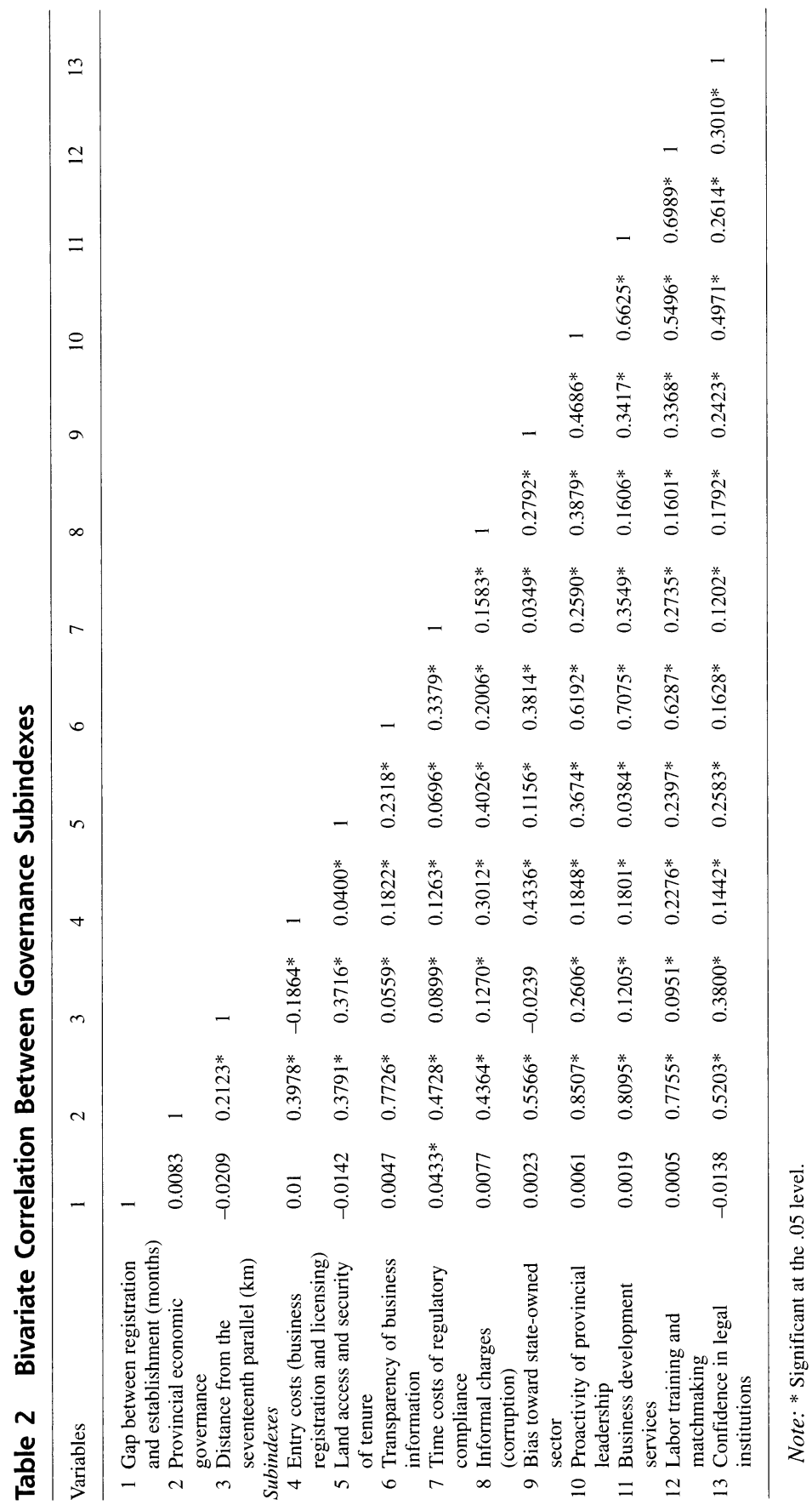


Table 3 Factor Analysis of Governance Subindexes

\begin{tabular}{lcccc}
\hline Variable & $\begin{array}{c}\text { Factor 1 } \\
\text { Policies }\end{array}$ & $\begin{array}{c}\text { Factor 2 } \\
\text { Property Rights }\end{array}$ & $\begin{array}{c}\text { Factor 3 } \\
\text { Entry Costs }\end{array}$ & Uniqueness \\
\hline $\begin{array}{l}\text { Land access and security } \\
\text { of tenure }\end{array}$ & 0.0684 & 0.8838 & -0.0593 & 0.2107 \\
$\begin{array}{l}\text { Informal charges } \\
\text { (corruption) }\end{array}$ & 0.0612 & 0.6881 & 0.3724 & 0.3841 \\
$\begin{array}{l}\text { Confidence in legal } \\
\text { institutions }\end{array}$ & 0.3276 & 0.4241 & 0.2274 & 0.6611 \\
$\begin{array}{l}\text { Business development } \\
\text { services }\end{array}$ & 0.9064 & -0.0553 & 0.1074 & 0.1639 \\
$\begin{array}{c}\text { Transparency of } \\
\text { business information }\end{array}$ & 0.835 & 0.0982 & 0.0916 & 0.2847 \\
$\begin{array}{l}\text { Labor training and } \\
\text { matchmaking }\end{array}$ & 0.8054 & 0.095 & 0.1282 & 0.3259 \\
$\begin{array}{l}\text { Proactivity of provincial } \\
\text { leadership }\end{array}$ & 0.7404 & 0.4251 & 0.2119 & 0.2261 \\
$\begin{array}{l}\text { Time costs of regulatory } \\
\text { compliance }\end{array}$ & 0.5174 & 0.0385 & -0.0988 & 0.7211 \\
$\begin{array}{l}\text { Entry costs (business } \\
\text { registration and }\end{array}$ & 0.0623 & 0.006 & 0.8587 & 0.2587 \\
$\begin{array}{l}\text { licensing) } \\
\text { Bias toward state- } \\
\quad \text { owned sector }\end{array}$ & 0.2906 & 0.1525 & 0.7511 & 0.3282 \\
$\begin{array}{l}\text { Eigenvalue } \\
\text { Cumulative variance } \\
\text { explained }\end{array}$ & $38.34 \%$ & 1.50 & 1.10 & \\
\hline
\end{tabular}

Note: Factor analysis performed with varimax rotation.

scores on property rights represent state retreat from intervention in the affairs of private firms, as opposed to the first factor, where good scores represent policy interventions. The final factor, responsible for the smallest portion in cumulative variance, comprises two subindexesentry costs and bias to the state sector - which address entry barriers to private entrepreneurs. Entry costs capture the direct financial costs of entry, whereas SOE bias represents the implicit barriers to private sector entry posed by the economic strength of the existing state sector or the ideological convictions of provincial bureaucrats.

Our core analysis utilizes the final 100-point PCI index. However, in the final section, we perform a separate analysis by subindex in order to explore which types of institutions are predominantly responsible for formalization decisions.

Figure 1 demonstrates the strong negative correlation between total economic governance (the unweighted PCI) and the total level of informality in the economy, which is operationalized by the percentage of total business investment in 2006 accounted for by the household 
Figure 1 Relationship Between Formalization and Aggregate Economic Governance

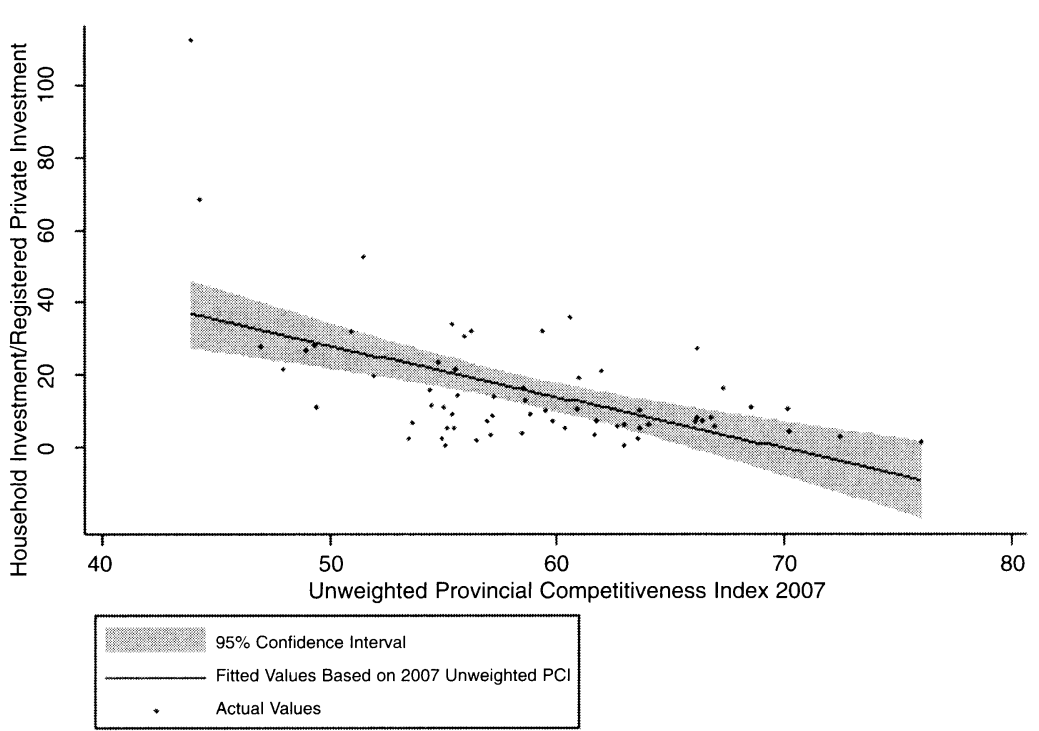

Source: General Statistics Office (2006). Non-Farm Individual Business Establishments Current and Solutions. Hanoi: Statistical Publishing House. Vietnam Provincial Competitiveness Index 2007 (www.pcivietnam.org).

sector. The bivariate correlation is robust to a multiple regression with structural control variables for infrastructure and provincial wealth, as well as alternative definitions of informality. ${ }^{8}$

\section{Data}

To test which institutions, if any, facilitate the formalization process, we use data from the 2007 version of the Vietnam PCI Survey, a comprehensive governance survey of 6,700 firms distributed across Vietnam's sixty-four provinces. The survey team randomly sampled from a list of private companies registered with each province's Tax Authority. Stratification was based on firm size, age, and broad sector (agriculture, services, construction, and industry) in order to accurately reflect populations in each province. The result is the most comprehensive and methodologically rigorous tool for assessment of the environment for private sector development in Vietnam to date. The subnational design of the study allows us significant variance on provincial endowments, 
even after holding constant the tricky differences in culture and history that create problems for cross-national studies of the same issues.

One limitation of the dataset is that it consists only of those businesses that eventually decided to formally register as companies. It does not include household companies that never registered. As a result, we have only found evidence of the influence of institutions on the formalization decision for a subset of this broader population at risk of formalization. We do show that our argument is robust to inclusion of the broader set of firms by demonstrating that institutions are correlated with aggregate formalization in each province. This test is admittedly imperfect but does provide some indication of the robustness of our findings, in the absence of a random sample of household enterprises. A second issue is that our institutional measures generally postdate the formalization decisions we study. This problem is relatively minor, as correlation of scores is extremely high across the years that the measure has been calculated, showing that institutions are sticky and do not change rapidly over time. Furthermore, our instrumental variables help sort out the causal process directly.

We proceed with data analysis in three main stages. First, we consider the role of the general local institutional environment in shaping an entrepreneur's decision of whether a new business should be set up as a household business or as a private company formally registered with provincial authorities. Second, we look deeper at how this environment influences the subset of firms that do begin in the relatively informal household sector and the length of time until they transition into the formal company sector. Finally, we consider which particular institutions have the greatest impact on the timing of formalization by this latter group.

\section{Dependent Variables}

The dependent variable of formal entry in the first stage of analysis is a simple dichotomous variable that equals " 1 " if the business either (1) answered no to a question about whether it had operated as a household business previous to registering as a company; or (2) did not report beginning operations in a year prior to the year it reported formally registering as a company. For robustness, we also test a more conservative dummy based only on the first group.

For the second stage, we create a count variable for all firms that scored a "l" on the broader of the first test dependent variables equal to the difference in months between year of establishment and the year 
of registration. In the vast majority of cases, this count variable equals " 0 ," meaning that the difference between establishment and registration happened during the same year and so was less than a year. Nevertheless, a substantial number of firms did have significant wait periods, leading to an average wait of 13.4 months and a maximum of fifteen years.

\section{Explanatory Variables}

The first and second stages of analysis focus on the influence of the broader institutional environment on formalization. We test this by utilizing each province's unweighted 2007 PCI score as our explanatory variable. Each of the ten PCI subindexes consists of both "hard" and "soft" measures. By hard measures, we mean statistics that reflect a particular outcome of the institutional environment and are available from published sources such as the GSO or Ministry of Finance. Soft measures, in turn, are those based on entrepreneurs' own subjective responses to survey questions about their institutional environment.

Measures of institutional development generally fall into one of these two categories. Hard measures are the more objective of the two, in that they are less subject to the biases of individual respondents across different localities and different industries. But, being more precisely defined, hard measures are also more likely to be incomplete measures of the reality of the institutional environment. In the case of a hard measure of particular legislation, for example, it is usually not possible to take into account the full spectrum of degrees of implementation. Similarly, in the case of a hard measure that measures the frequency of a particular legal action or outcome, issues of quality of action or outcome are neglected. These weaknesses in hard measures can be addressed through the use of soft measures-that is, qualitative surveys of actors in the field-that gauge the business community's take on the actual implementation and overall effect of government policies. Because both hard and soft data have strengths and weaknesses, the most appropriate methodology should clearly distinguish between the two but consider both (Woodruff 2006).

After establishing the general importance of the institutional environment to the formalization decision through use of the aggregate index, we conclude with initial consideration of which specific institutions are most relevant. We do this by replicating our earlier regression on time spent in the informal sector, successively replacing the aggregated PCI with each of its individual subindexes. 


\section{Control Variables}

Our analysis controls for a series of firm-, entrepreneur-, and locationlevel characteristics that could be thought to influence the formalization decision.

At the level of the firm, we include a control for the timing of establishment, which in some regressions we represent with years since establishment and in other cases represent as years since establishment paired with its squared term to account for the possibility that institutional change has been more rapid in recent years. ${ }^{9}$ We further control for a firm's status as an exporter (or not), the zoning of the land on which it operates (residential or not), equity capital at time of establishment, broad economic sector, and ISIC code. Broad economic sector refers to dummies for classification as primarily agriculture, industry, services, or construction, while ISIC codes are considered at both the one- and two-digit levels.

The entrepreneur characteristics we consider relate to past personal experience working for the state. Considering the highly political nature of regulation in Vietnam, such connections have been shown to provide advantages to entrepreneurs (Nguyen et al. 2004; O'Conner 2000; Webster and Taussig 1999). These controls include a dummy for whether an entrepreneur is a former government bureaucrat or SOE manager and another for whether the entrepreneur is a former SOE employee.

In addition to our key explanatory variables, we include a number of other location-based control variables. To control for infrastructure and socioeconomic conditions, we control for telephones per capita, percentage of population that represents secondary school graduates, share of the population composed of people not of the majority Kinh ethnicity, and GDP per capita; we also include a dummy for provincial status cities. To consider the effect of Vietnam's unique history, we introduce a dummy for location in what was once commonly known as South Vietnam and regional-fixed effects. ${ }^{10}$

\section{Results}

The decision tree of formalization for entrepreneurs in Vietnam has three nodes. First, business owners must decide whether to start operations as a formal or household enterprise. Entrepreneurs who begin in the household sector must next decide whether or not to move from the informal sector. If they opt in favor of such a movement, how long will 
they wait until formalization? In this section, we test direct firm-level evidence on the initial start-up decision and the length of time spent in the household sector. ${ }^{11}$

\section{Analysis of Initial Start-up Decision}

In Table 4, using a probit model, we test the likelihood that an individual entrepreneur will choose to begin initial operations in the formal sector. Model 1 contains the key causal variable of economic governance, measured by the PCI 2007 along with firm-level controls. Model 2 then adds information on the personal characteristics of entrepreneurs. Models 3 and 4 add in location-specific controls. Model 5 addresses unobserved heterogeneity with sector-fixed effects, based on whether the firm operated primarily in agriculture, services, construction, or industry. Models 6 and 7 substitute more refined industry-fixed effects using the ISIC 1- and 2-digit coding systems. Model 8 adds regional-fixed effects, while Model 9 replaces entry timing control variables with establishment year-fixed effects. For robustness, we also include Model 10, which replaces the main dependent variable with a new variable based on the narrower definition of each firm's self-assessment of whether it began as a household enterprise.

Our key explanatory variable for provincial economic governance has a significantly positive effect on selection into the formal sector in each of the seven models. In the fully specified Model 5, a 10-point increase in economic governance increases the probability of formal entry by 2.5 percent. This is consistent with our general expectation that better institutions will encourage greater participation in the formal sector.

Our firm-level control for equity capital at establishment shows that formality is more likely when entrepreneurs start up larger firms. Start-up capital has a strong positive impact, below the 0.01 level of statistical significance, in each model. In contrast, we find 12.5 times lower likelihood that firms operating on land zoned for residential purposes will choose to start up in the formal sector. This is consistent with the idea that businesses that start out of the home are likely to begin in a more cautious, exploratory fashion than those that are set up on land specifically designated for business. To our surprise, we find no significant relationship in any of the models between a firm's status as an exporter and the odds that it entered as a formal enterprise.

Personal connections to the state significantly increase the odds that an entrepreneur will select into the formal sector. This is true 


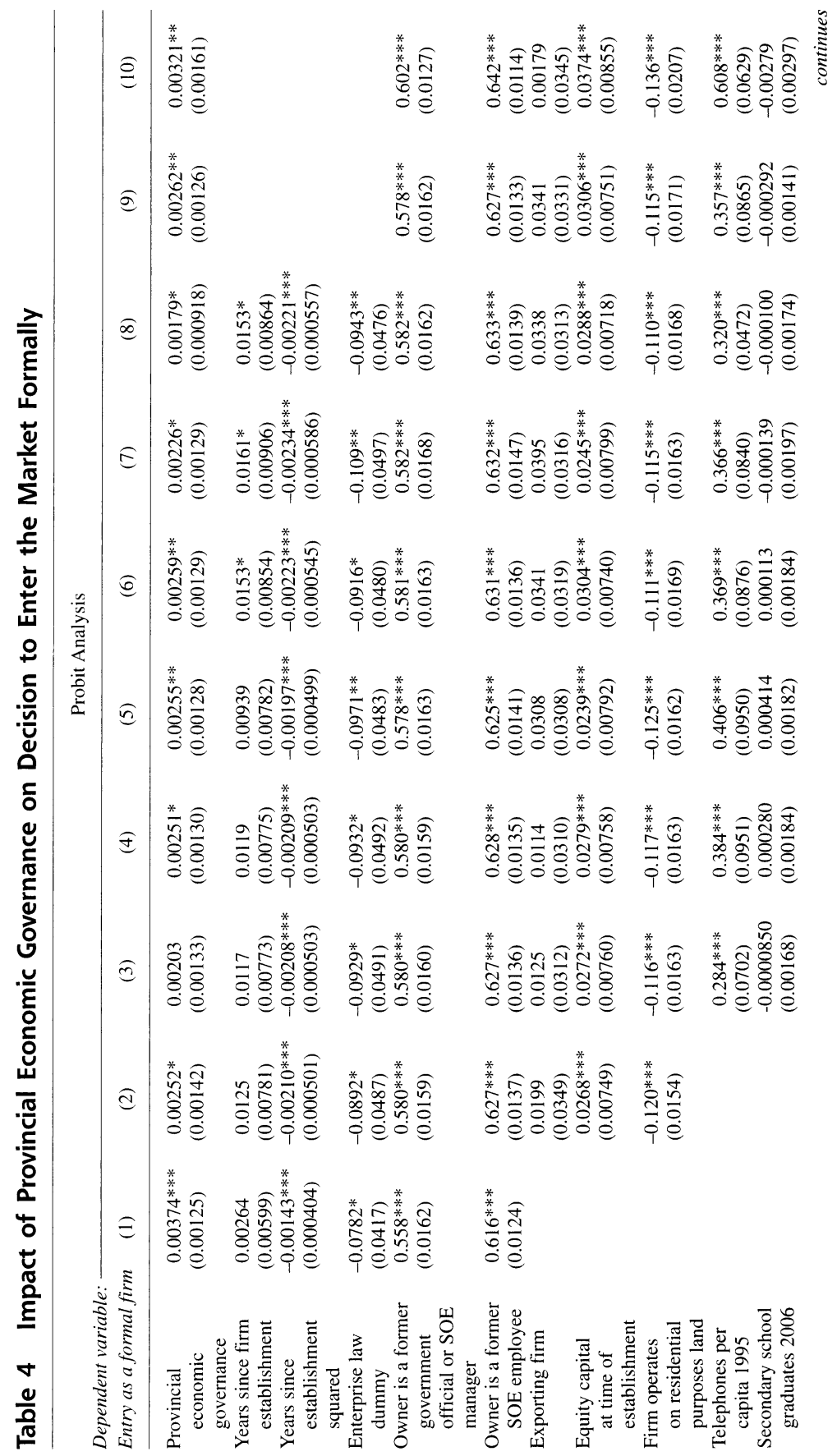




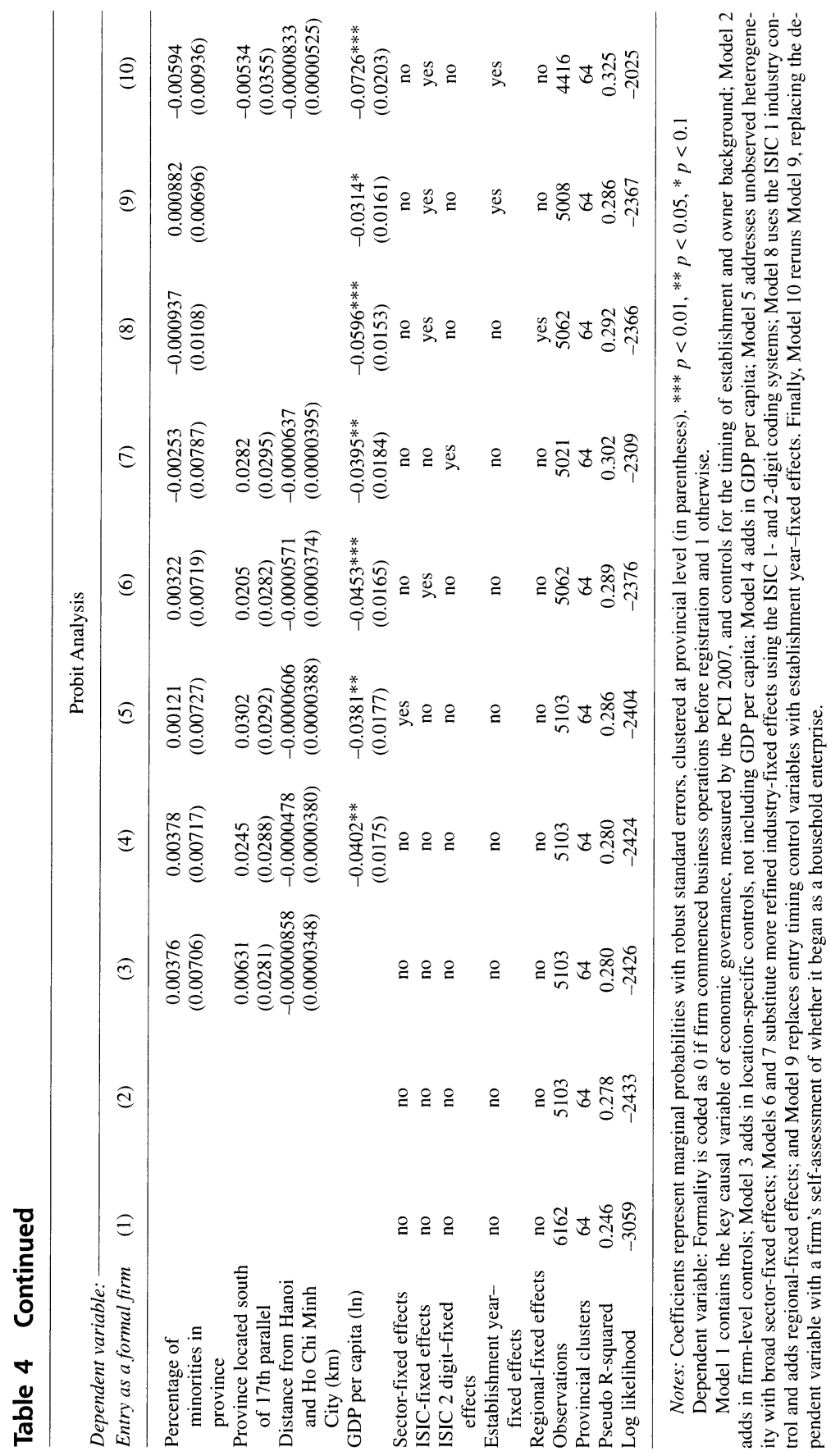


whether the connection is experience as a government bureaucrat or SOE manager or, on a lower level, as a former SOE employee. This is consistent with a number of possible explanations. First and foremost, there is evidence that such connections are useful in accessing scarce business resources needed for growth in Vietnam's still imperfect business environment (Malesky and Taussig 2008). Second, in some industries, state employment was, in the recent past, still the best place to accumulate relevant experience for starting a growth-oriented business. And finally, for those entrepreneurs who left state employment of their own will, only a growth-oriented business opportunity is likely to have tempted them away from the stability of state employment. Results for these entrepreneur-level variables are again strongly significant across all models and substantively important. SOE managers and employees are 58 percent and 62 percent more likely to begin operations formally.

Only two of the location-based control variables prove to have any influence on our probit analyses. In Models 2 through 7, higher numbers of telephones per capita in a firm's province consistently lead to a higher likelihood of that firm's choosing formal status upon entry. In contrast, across the same set of models, higher logged per capita GDP makes the choice of formality less likely. This result is somewhat surprising, given the reverse causality expectation that higher levels of formality would mean higher levels of growth-oriented businesses and therefore higher levels of wealth. Higher levels of wealth, however, also likely mean greater demand for local services and, holding institutions constant, may make it less worthwhile for authorities to closely regulate smaller businesses. We find no significance at all for the effect of secondary education levels, share of minorities, or location in the historically more market-oriented southern half of the country.

\section{Analysis of Wait Between Establishment and Formalization}

Our second test considers the relationship between provincial institutions and the length of time a firm spent as a household enterprise before making the formalization decision. In Table 5, we analyze the subsample of firms that did make the original decision to begin operations in the informal sector. In sum, it appears that the impact of governance institutions on formalization is statistically significant, substantively large, and robust across a range of different specifications. 


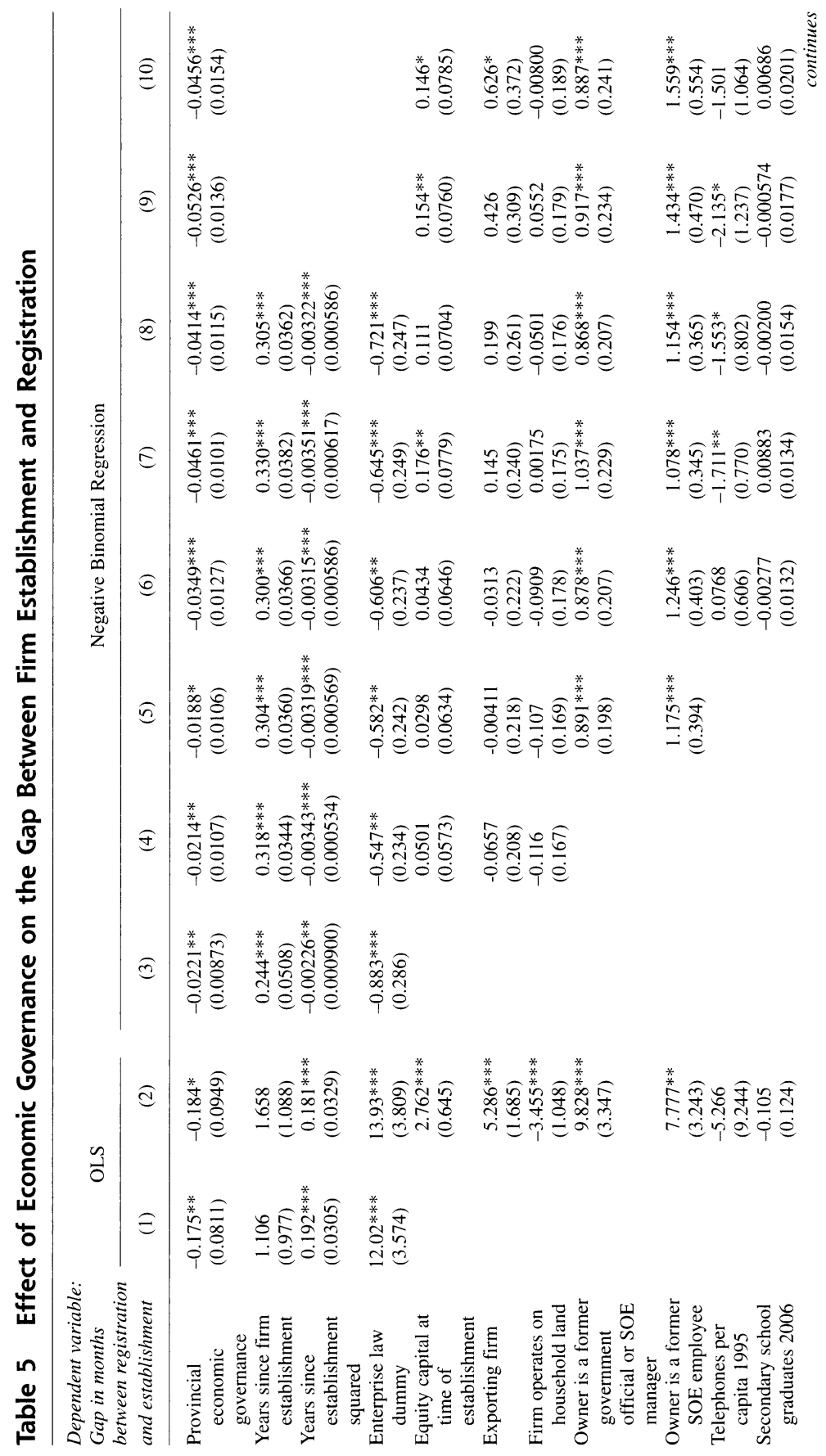




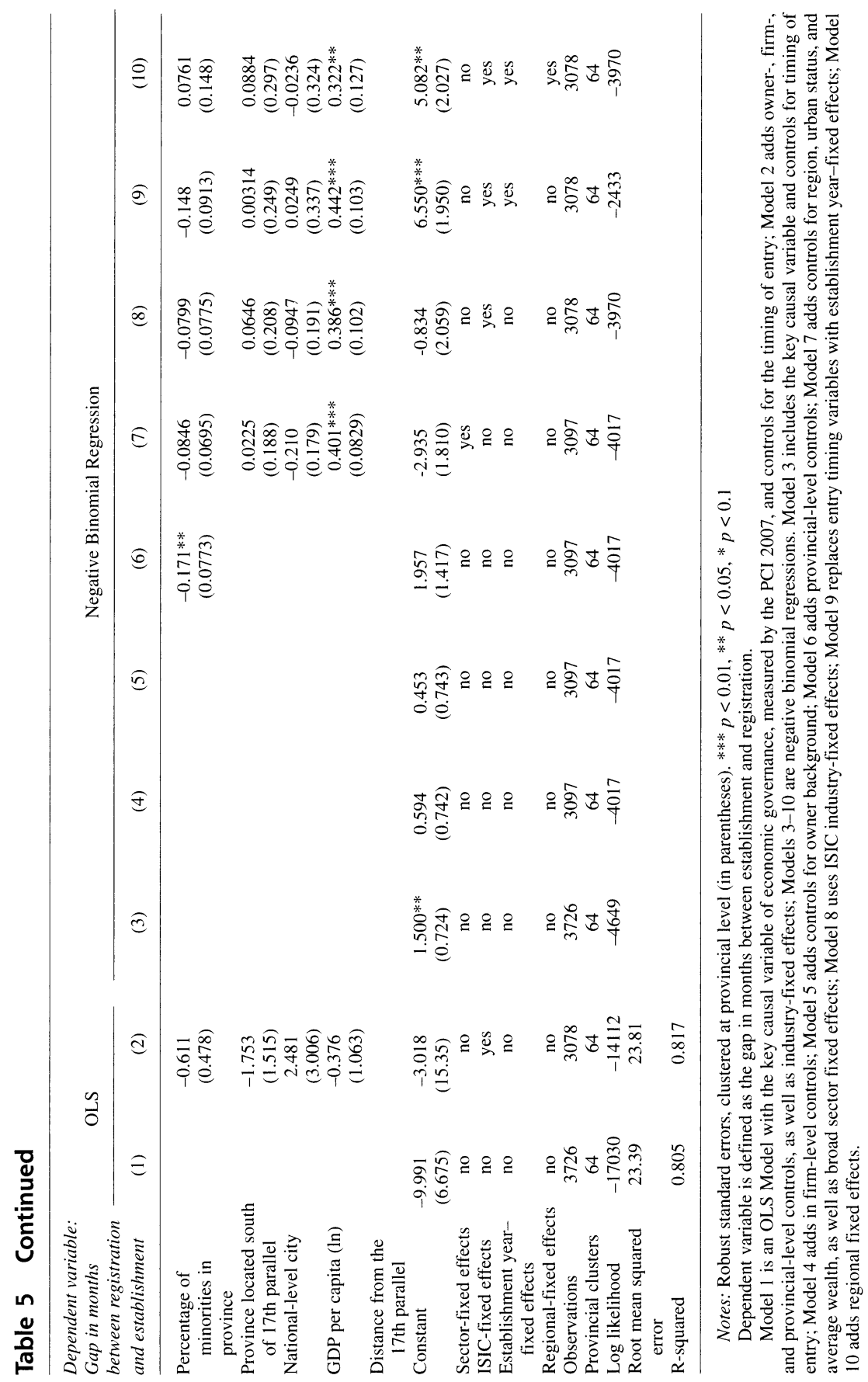


Model 1, an OLS model including only economic governance as the key explanatory variable and controls for the general improvement in the national regulatory environment over time, provides initial support for our hypothesis that higher-quality institutions will reduce the time a firm spends in the informal sector before formalization. This finding survives the addition of provincial-level controls and industryfixed effects in Model 2.

OLS assumes continuous, normally distributed dependent variables, not count variables as is the case in this analysis. As such, we find more robust support for our hypothesis with Models 3 through 10, which apply a negative binomial (nbreg) methodology that accounts for the unique properties of count variables with substantial numbers of zero values. ${ }^{12}$ Results do not change substantially in response to adding sector-fixed effects in Model 7, age and industry-fixed effects in Model 8, and regional-fixed effects in Model 9. In sum, a 10-point improvement on the 100-point unweighted economic governance index yields a reduction of approximately half a month spent in the informal sector.

This point estimate is highly contingent on whether the firm chose to formalize before or after the Enterprise Law. Those registered before the Enterprise Law spent on average an extra fourteen months in the informal sector. Figure 2 divides the predicted effect of good governance between firms registered before and after the regulatory changes introduced by the Enterprise Law. Provinces with good governance are conservatively defined as those with index scores above the median of 58.5. Using this delineation, we find that both before and after the Enterprise Law, firms in well-governed provinces spent significantly less time in the informal sector. Before the Enterprise Law, the gap between well-governed and poorly governed locations was an astonishing twenty-six months. After the law, the gap decreased substantially to 0.6 months (about five days) but remained statistically significant at the 0.05 level.

The most consistent and strongly significant result among the control variables is that entrepreneurs with backgrounds in state employment spend substantially more time in the informal sector. This is interesting, in that it is the opposite relationship with informality from the one found at the start of operations. This contrast implies that there are two distinct types of connected entrepreneurs. The first group is made up of those who use their connections primarily as means for accessing scarce business resources. These entrepreneurs are most likely to begin operations as formal companies. The second group consists of those 


\section{Figure 2 Predicted Gap Between Registration and Establishment} (by level of governance and age of firm)

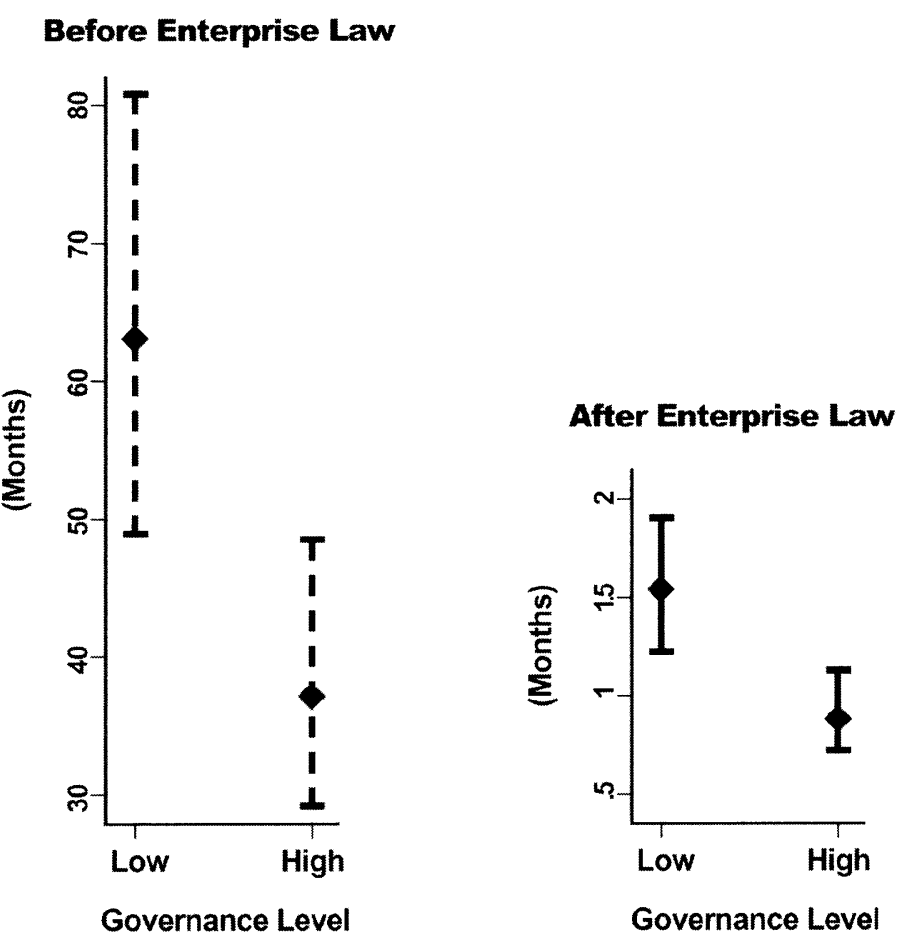

Note: Low and High are defined relative to the median score (58.49) on the 2007 Vietnam Provincial Competitiveness Index. The Enterprise Law was formally promulgated in 2000. Firms established in 2000 or later are considered after the law. Results are the predicted marginal effects from Table 5, Model 8 using Clarify (King, Tomz, and Wittenberg 2000); 95 percent confidence intervals are drawn around each point estimate.

who use their connections primarily to minimize government regulation of their operations. These would be the entrepreneurs who choose the informal sector and stay there for a relatively longer period of time. These same entrepreneurs may also be more risk averse, taking longer to leave their state positions, preferring to maintain both the stability of their government jobs and to, at first, just supplement this income with minimal rents from their informal businesses. At this point, our data do not allow us to distinguish between these two distinct groups, but these results call out for future work. 
The only province-level control that is consistently significant in the negative binomial models is GDP per capita, which always has a substantively large and statistically significant coefficient. This is consistent with our probit results, indicating that, keeping the quality of local institutions constant, markets with larger demand and likely greater numbers of larger firms make greater amounts of informality more likely. The negative binomial models also provide limited evidence that better physical infrastructure, proxied for by more telephones, means less time in the informal sector, as does a greater share of minorities in the province. Other province-level controls are also insignificant with the negative binomial specification.

\section{Identification Strategy for Isolating the Effect of Institutions on Formalization}

We address the issues of endogeneity by implementing an instrumental variable approach. The objective is to bolster our causal argument by guarding against two possibilities. First, there is reason to suspect reverse causality. Provinces with higher levels of prior formalization will have a larger tax base to draw on for improving government capacity. As a result, the causal arrow may run from formalization to institutional quality (Kurtz and Shrank 2007). If this is true, formalization would lead to good governance or at least the perception of good governance from PCI respondents. While reverse causality is unlikely, as even formal firms represent a relatively small share of current provincial budgets, the cross-sectional nature of our panel does not allow us to immediately dismiss the possibility.

Second, while our within-country design diminishes this problem to a large extent, we must still guard against unobserved heterogeneity. Underlying cultural and historical factors at the province level may play a role in encouraging both formalization and more rules-based governance on the part of local officials. In Vietnam, the North's and South's very different histories with capitalist business activity is a particular concern. It has been argued that politicians in the South may have had greater experience with entrepreneurial activity and therefore are more likely to construct institutions conducive to its development (Turley and Womack 1998; Nguyen et al. 2004). In this case, both greater formalization and good governance would be influenced by historical experience. The models we have cited may be misattributing 
causation. A simple southern dummy would be too blunt to address the problem if the bivariate correlation between the continuous measures of formality and governance was sufficiently strong.

To ensure that our results survive these two forms of endogeneity bias, we use a two-staged instrumental variables approach to ensure that exogenously determined economic governance is correlated with the decision of individual entrepreneurs to formalize their operations. To do this, we first need an instrument that is strongly correlated with economic governance but is not correlated with the error term in the second-stage equation predicting formalization. Doing so will allow us to solve a modified form of the traditional regression equation, where we can be sure that the causal chain runs through governance to formalization.

As our instrument, we use the distance for each province between its capital and the infamous seventeenth parallel. The seventeenth parallel was quite arbitrarily chosen at the Geneva Accords in 1954 as the border between the two new countries that would be known as North Vietnam and South Vietnam. In choosing this as our instrumental variable, we build on a logic introduced by Edward Miguel and Gerard Roland (2006) and also followed by Matthew Kocher, Thomas Pepinsky, and Stathis Kalyvas (2008). Both papers argue evidence that damage from war grew as one approached the former border that once divided Vietnam, showing specifically that distance to the seventeenth parallel is a strongly significant predictor of bombing intensity during the war. Miguel and Roland, in particular, use the seventeenth parallel as an instrument for the intensity of bombing in an effort to show that bombing had minimal long-term impact on future poverty across Vietnam.

We do not disagree with the Miguel and Roland empirics. They demonstrate persuasively that the seventeenth parallel is associated with bombing intensity and that exogenous bombing is not associated with spatial variance in poverty alleviation. Nevertheless, we do disagree slightly with the causal implications of their argument. The limited variance in poverty has less to do with similar growth and industrial production rates across bombed and unbombed regions than it does with an explicit effort by the Vietnamese government to transfer funds to war-damaged and poor regions (World Bank 2002). Miguel and Roland $(2006,21)$ concede this point at the end of the paper when they analyze the correlation between distance from the seventeenth parallel and state investment between 1975 and 1986.

The high level of transfers continues even to this day. Figure 3 shows the correlation between distance and average transfers per 100,000 citizens between 2000 and 2006. Panel A shows that the dis- 
Figure 3 Relationship Between Distance from the 17th Parallel and Fiscal Transfers
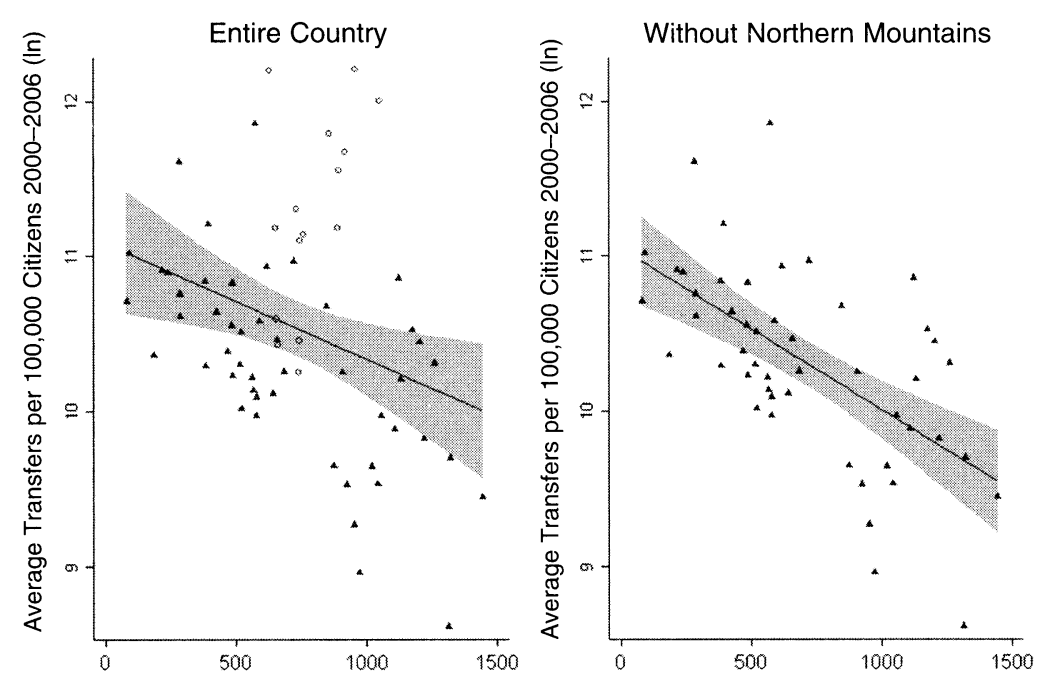

Distance from the 17th Parallel (km)

Note: Circles in Panel A represent northwestern provinces, while triangles are fitted values for all other provinces in the country. Shaded region represents a 95 percent confidence interval. Bivariate correlations depicted are -.33 (significant at 0.01 level) for Panel A and .61 (significant at 0.01 level) for Panel B. Data on transfers is from the 2000-2006 annual budgets. See www.mof.gov.vn.

tance is negatively correlated with transfers, a relationship that is significant at the 0.01 level. But this relationship includes the poor, underdeveloped northwestern region of Vietnam (marked with circles), which under the formula-based transfer system also receives a disproportionately high share of programmatic block grants. Dropping the northwest region further enhances the already strong correlation. Dependence on investment from SOEs shows a similar pattern (see Figure 4). Provinces close to the seventeenth parallel had higher-level SOEs operating well into the reform era (Panel A) and have been much slower about privatizing or liquidating these operations (Panel B). Malesky (2009) demonstrates that due to the unique Vietnam financial system, which provides incentives for favoring a dominant sector, provinces with large state sectors tend to have governance institutions that are biased against private actors.

In sum, damage during the war led provincial governments to be more dependent on budget transfers and state resources from the cen- 
Figure 4 Relationship Between Distance from the 17th Parallel and Dependence on State Sector
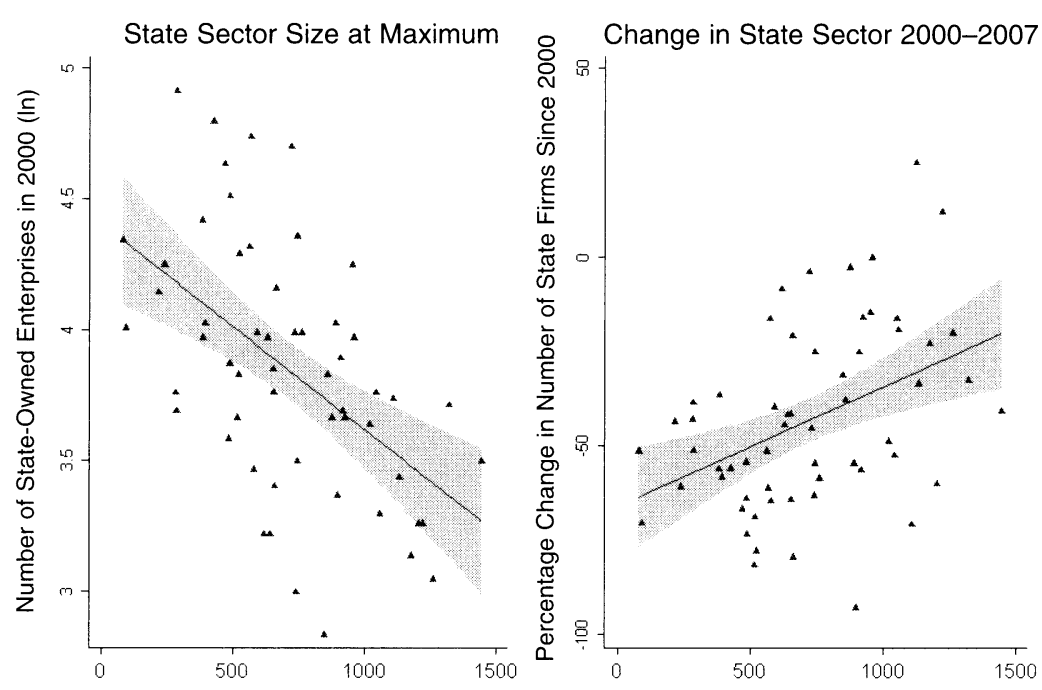

Distance from the 17th Parallel $(\mathrm{km})$

Note: Triangles represent fitted values for all provinces in the country. Shaded region denotes a 95 percent confidence interval. Bivariate correlations depicted are -0.20 (significant at 0.1 level) for Panel A and 0.45 (significant at 0.05 level) for Panel B. Data on enterprises are from the General Statistical Office Enterprise Census (www.gso.gov.vn).

tral government. This, in turn, led them to be more susceptible to the changing whims of factionalized political leadership throughout Vietnam's ongoing experiment with market reforms, and also less likely to engage in their own initiatives to build up local market institutions. Miguel and Roland's finding that damage from bombing does not help predict present-day poverty levels is evidence of the serious, and indeed quite effective, efforts by Vietnam's central government to rebuild these parts of the country and to acknowledge their sacrifice. This logic that regions close to the seventeenth parallel were less likely to develop effective local market institutions is reinforced by the Kocher et al. (2008) discovery that more heavily bombed regions tended to be stronger bastions for the National Front for the Liberation of South Vietnam (Viet Cong), which later translated into greater ideological support for the Communist government in Hanoi.

As Table 2 shows, preliminary evidence for use of distance from the seventeenth parallel is compelling. The bivariate correlation between distance and the PCI is 0.21 and significant at the 0.05 level, 
while the correlation between distance and time spent in the informal sector is -0.02 and not significantly different from zero. This is tentative confirmation that our instrument meets the exclusion criterion of IV-2SLS.

Table 6 contains a package of models associated with the IV-2SLS procedure. Columns 2 and 3 provide the critical first and second stages. As is immediately obvious, the instrument is significantly correlated with economic governance; the farther a province is from the seventeenth parallel, the better its PCI scores, all else equal. The second stage confirms our overall theory that good institutions are associated with lower time spent in the informal sector. Diagnostic tests, presented at the bottom of Table 6 , confirm that our instrument is strong and appropriately identified.

Alternative pathways between the instrument and formalization are addressed by control variables. The percentage of secondary school graduates accounts for the fact that economic elites had more resources available to escape from war-damaged provinces, and this group was more likely to start new businesses than laborers who were trapped in war-torn regions. Distance from Hanoi and Ho Chi Minh City accounts for the fact that distance from the seventeenth parallel is also correlated with distance from these major metropolises and the greater opportunities their large markets provide for business success. The second-stage impact of governance can be considered to be the net effect on formalization after addressing these other channels.

\section{Disaggregating Institutions That Influence Formalization}

Finally, we investigate how specific types of institutions may affect formalization by replicating our analysis of the gap between establishment and formalization seventeen times, each iteration replacing our general institutions explanatory variable with the three factors generated in Table 7 (Panel 1), the ten PCI subindexes (Panel 2), and four individual indicators of economic governance that are hard measures, free of firm perception bias and halo effects (Panel 3). We display the coefficients on the key causal variables and standard errors in Table 7. Control variables remain the same as the previous specification in Table 5.

The results are consistent across the panel of Table 7: The driving institutional factor in the determination of formalization is property rights. Beginning at the broadest level, the only factor associated with 
Table 6 Instrumental Variables Analysis of Formalization

\begin{tabular}{|c|c|c|c|}
\hline $\begin{array}{l}\text { Dependent variable: Gap in months } \\
\text { between registration and establishment }\end{array}$ & Baseline & 1st Stage & 2nd Stage \\
\hline Provincial economic governance & & & $\begin{array}{c}-1.126^{*} \\
(0.661)\end{array}$ \\
\hline Years since firm establishment & $\begin{array}{c}0.0818 \\
(0.0717)\end{array}$ & $\begin{array}{c}0.0595 \\
(0.0644)\end{array}$ & $\begin{array}{c}1.719 \\
(1.081)\end{array}$ \\
\hline Years since establishment squared & $\begin{array}{l}-0.00148 \\
(0.00124)\end{array}$ & $\begin{array}{c}-0.000906 \\
(0.00106)\end{array}$ & $\begin{array}{l}0.180^{* * *} \\
(0.0326)\end{array}$ \\
\hline Enterprise Law dummy & $\begin{array}{c}0.00680 \\
(0.550)\end{array}$ & $\begin{array}{c}0.0681 \\
(0.507)\end{array}$ & $\begin{array}{l}13.84 * * * \\
(3.716)\end{array}$ \\
\hline Equity capital at time of establishment & $\begin{array}{c}0.0730 \\
(0.119)\end{array}$ & $\begin{array}{c}0.0826 \\
(0.108)\end{array}$ & $\begin{array}{l}2.833 * * * \\
(0.614)\end{array}$ \\
\hline Exporting firm & $\begin{array}{c}0.297 \\
(0.445)\end{array}$ & $\begin{array}{c}0.308 \\
(0.420)\end{array}$ & $\begin{array}{l}5.492 * * * \\
(1.740)\end{array}$ \\
\hline Firm operates on household land & $\begin{array}{c}0.0900 \\
(0.159)\end{array}$ & $\begin{array}{c}0.107 \\
(0.152)\end{array}$ & $\begin{array}{l}-3.386 * * * \\
(1.043)\end{array}$ \\
\hline $\begin{array}{l}\text { Owner is a former government official or } \\
\text { SOE manager }\end{array}$ & $\begin{array}{c}-0.328 \\
(0.305)\end{array}$ & $\begin{array}{c}-0.285 \\
(0.298)\end{array}$ & $\begin{array}{l}9.599 * * * \\
(3.253)\end{array}$ \\
\hline Owner is a former SOE employee & $\begin{array}{r}0.0367 \\
(0.387)\end{array}$ & $\begin{array}{c}0.347 \\
(0.327)\end{array}$ & $\begin{array}{l}7.919 * * \\
(3.125)\end{array}$ \\
\hline Telephones per capita 1995 & $\begin{array}{c}-7.975 \\
(9.711)\end{array}$ & $\begin{array}{l}-2.904 \\
(10.28)\end{array}$ & $\begin{array}{l}-12.60 \\
(12.07)\end{array}$ \\
\hline Secondary school graduates 2006 & $\begin{array}{c}0.106 \\
(0.184)\end{array}$ & $\begin{array}{c}0.251 \\
(0.189)\end{array}$ & $\begin{array}{c}-0.0239 \\
(0.250)\end{array}$ \\
\hline Percentage of minorities in province & $\begin{array}{c}-1.921^{* *} \\
(0.748)\end{array}$ & $\begin{array}{l}-2.019^{* * *} \\
(0.655)\end{array}$ & $\begin{array}{l}-2.490 \\
(1.638)\end{array}$ \\
\hline Province located south of 17 th parallel & $\begin{array}{c}3.868^{*} \\
(2.015)\end{array}$ & $\begin{array}{l}4.062 * * \\
(2.010)\end{array}$ & $\begin{array}{c}1.641 \\
(3.940)\end{array}$ \\
\hline National-level city & $\begin{array}{c}0.956 \\
(3.141)\end{array}$ & $\begin{array}{l}-0.212 \\
(3.679)\end{array}$ & $\begin{array}{c}3.324 \\
(4.393)\end{array}$ \\
\hline GDP per capita (ln) & $\begin{array}{c}0.962 \\
(0.941)\end{array}$ & $\begin{array}{l}0.173 \\
(0.925)\end{array}$ & $\begin{array}{c}0.598 \\
(1.678)\end{array}$ \\
\hline Distance from the 17th Parallel & & $\begin{array}{r}0.00509 * \\
(0.00271)\end{array}$ & \\
\hline Constant & $\begin{array}{l}42.47 * * \\
(18.07)\end{array}$ & $\begin{array}{l}32.10^{*} \\
(18.53)\end{array}$ & $\begin{array}{c}38.63 \\
(36.51)\end{array}$ \\
\hline Sector-fixed effects & no & no & no \\
\hline ISIC-fixed effects & yes & yes & yes \\
\hline Establishment year-fixed effects & no & no & no \\
\hline Regional-fixed effects & no & no & no \\
\hline Observations & 3298 & 3298 & 3078 \\
\hline Provincial clusters & 63 & 63 & 63 \\
\hline Log likelihood & -10129 & -10022 & -14116 \\
\hline Root mean squared error & 5.219 & 5.053 & 24.21 \\
\hline $\mathrm{R}$-squared & 0.332 & 0.374 & 0.809 \\
\hline Cragg-Donald F-statistic & & $209.9 * * *$ & \\
\hline Anderson canonical correlation LR statistic & & $204.7^{* * *}$ & \\
\hline Endogeneity test & & $5.695^{* *}$ & \\
\hline
\end{tabular}

Notes: Robust standard errors, clustered at provincial level (in parentheses). ${ }^{* * *} p<0.01,{ }^{* *} p<0.05$, $* p<0.1$

Dependent variable is defined as the gap in months between establishment and registration.

This presents a series of three models for the IV-2SLS procedure. The first two columns show a baseline first stage without the instrument, followed by the actual first stage where economic governance is regressed on distance from the 17th parallel. The final model shows the complete second-stage results. 


\section{Table 7 Effect of Subindexes and Indicators of Economic Governance on Formalization}

\begin{tabular}{|c|c|}
\hline Factors & Coefficient \\
\hline 1 Policies & $\begin{array}{l}-0.687 \\
(0.65)\end{array}$ \\
\hline 2 Property rights & $\begin{array}{c}-1.389 \\
(0.77)\end{array}$ \\
\hline 3 Entry barriers & $\begin{array}{c}-0.312 \\
(0.51)\end{array}$ \\
\hline Subindex & Coefficient \\
\hline 1 Entry costs (business registration and licensing) & $\begin{array}{c}-0.750 \\
(0.80)\end{array}$ \\
\hline 2 Land access and security of tenure & $\begin{array}{l}-2.258^{* *} \\
(1.08)\end{array}$ \\
\hline 3 Transparency of business information & $\begin{array}{r}-0.764 \\
(0.49)\end{array}$ \\
\hline 4 Time costs of regulatory compliance & $\begin{array}{l}-0.395 \\
(0.68)\end{array}$ \\
\hline 5 Informal charges (corruption) & $\begin{array}{l}-1.059 \\
(1.32)\end{array}$ \\
\hline 6 Bias toward state-owned sector & $\begin{array}{l}-0.477 \\
(0.84)\end{array}$ \\
\hline 7 Proactivity of provincial leadership & $\begin{array}{c}-0.468 \\
(0.34)\end{array}$ \\
\hline 8 Business development services & $\begin{array}{l}-0.0814 \\
(0.45)\end{array}$ \\
\hline 9 Labor training and matchmaking & $\begin{array}{c}-0.632 \\
(0.46)\end{array}$ \\
\hline 10 Confidence in legal institutions & $\begin{array}{l}-1.030^{*} \\
(0.54)\end{array}$ \\
\hline Hard indicators of institutions & Coefficient \\
\hline 1 Median days to register business & $\begin{array}{l}-0.0268 \\
(0.11)\end{array}$ \\
\hline 2 Percentage of titled land in province & $\begin{array}{l}-0.0611^{* *} \\
(0.028)\end{array}$ \\
\hline 3 Web page transparency & $\begin{array}{l}-0.0716 \\
(0.15)\end{array}$ \\
\hline 4 Percentage of legal cases filed by private firms & $\begin{array}{l}8.881 \\
(10.5)\end{array}$ \\
\hline
\end{tabular}

Notes: Robust standard errors, clustered at province level (in parentheses); ${ }^{* * *} p<0.01$, $* * p<0.05, * p<0.1$.

Each row replicates Model 2 of Table 5, but with Total Economic Governance replaced by the subindexes that comprise it.

To save space only the coefficients and standard errors on key causal variables are reported. 
changes in formalization is the one we labeled property rights, because of its strong correlations with land access and security, confidence in legal institutions, and informal charges. A one standard deviation change in this factor would yield a 1.4-month decline in the gap between establishment and registration. Confirming this finding, the strongest results for the individual subindexes are land access and confidence in legal institutions. The substantive effect of improving the security of business premises is particularly large. A one-point change in the subindex is associated with a 2.3-month decline in the waiting period for formalization. Informal charges is the only subindex strongly associated with property rights that is not independently significant. This is not to say that informal charges do not matter for formalization, but their effect is likely mitigated by more secure property rights and stronger appeals processes through legal institutions.

The insignificance of entry costs is less surprising, as the Enterprise Law decreased the variance in entry costs across provinces significantly. Only a few days separate waiting periods in the highest and lowest provinces, and it is unlikely that this marginal difference has much of an impact on entrepreneurs' decisions.

Because these indexes are generated by firm surveys, there is potential that perception biases, particularly halo effects, may be responsible for the association. As a robustness test, we rerun the analysis only with hard indicators that are not derived from the survey. These include (1) a measure of the median days for firm registration recorded by the Vietnamese Ministry of Planning and Investment as a proxy for entry costs; (2) a measure of the total amount of land in each province that has a formal land use rights certificate (LURC) from the Ministry of Natural Resources and the Environment to gauge property rights; (3) a twenty-point evaluation of the business information available on provincial websites to proxy for transparency; and (4) the percentage of claims filed in provincial courts by private firms, gauging private sector confidence in legal institutions.

The results of this analysis are displayed in the third panel. Once again, only the proxy for the security of property rights is statistically significant. Firms in provinces that have made advances in granting LURCs are significantly less likely to remain in the informal sector. In many ways, this result distills the essence of the property rights. As a result of the 1993 Land Law, provinces were obligated to grant longterm leases on land in the province to current holders. The leases called LURCs were for periods as long as ninety years and could be exchanged, sublet, and used as collateral on bank loans (Do and Iyer 
2008). Holders of these certificates have much more secure protection of their business activities (Haare 2008) and, as a result, titled land is significantly more valuable than land without a LURC (Kim 2004).

The wide variation in the allocation of LURCs that has existed throughout the reform era continues to this day (Ravallion and van de Walle 2006). Currently, the percentage of titled land ranges from 19.5 percent in the northwestern province of Tuyen Quang to 98.8 percent in the Mekong Delta's Vinh Long province. The data demonstrate that the simple process of allocating these certificates encourages formalization of business activities, confirming one of De Soto's (2000) most famous hypotheses and the Sebastian Galiani and Ernesto Schargrodsky (2007) discovery that land titles incentivize entrepreneurial behavior through the long-term security they provide.

\section{Conclusion}

The decision of whether or not to select into the formal economic sector is a crucial strategic decision faced by all entrepreneurs. This decision can be made at any point in the life of a firm. To a significant extent, it is a choice between ambitions-that is, whether to be a growth-oriented entrepreneur or a more risk-averse subsistence-oriented entrepreneur. This decision is particularly complex under the more difficult conditions typical of developing countries.

In this article, we capitalize on variation in the tendency to formalize among entrepreneurs across provinces in Vietnam to investigate the influence of local institutions on formalization. We find strong evidence that better institutions make entrepreneurs more likely to choose the more growth-oriented path of formality. This evidence provides empirical support for public policy agendas that predict that cleaner, more predictable government institutions lead to greater entrepreneurial dynamism and economic growth.

Furthermore, it appears as though higher-quality property rights are particularly relevant to enterprise formalization. While there is clearly a need for further investigation on this important point, land titling, in particular, may provide a cheap and effective policy tool for encouraging household businesses to formalize. By simply granting better property rights for existing plots, local officials can spur on formalization and achieve quick benefits in additional tax revenues and growth-oriented entrepreneurship. The strength of the land title measure raises interesting avenues for further research. 
There are two channels by which land titles could facilitate formalization. The first is that LURCs allow entrepreneurs to feel secure that their business premises will be protected for the foreseeable future. That knowledge lengthens the business time horizons of operations, allowing entrepreneurs to consider riskier and more expensive operations. Indeed, Galiani and Schargrodsky (2007) show that households with land titles in Argentina were more likely to take on expensive residential improvements, such as new roofs and walkways. Galiani and Schargrodsky did not explore business decisions, but the logic of titles incentivizing investment is analogous. There is some possibility that the greater openness that transparency entails may engender more bribe requests, but at least entrepreneurs need not fear having the business premises yanked from under a successful operation through expropriation.

Second, land titles can promote greater access to credit, because they can be offered as collateral (De Soto 2000). Increased credit could, in turn, raise the prospects of business expansion and consequently the perceived benefits of formalization. The Argentina experiment found little evidence of increased credit, but their unit of analysis was the family residence, so they primarily explored mortgage and grocery store credit. They did not consider more entrepreneurial ventures, which would be primarily interested in bank loans. The value of LURC collateral may be more attractive for bankers when the property is in a business district and not a residential area.

Future research will seek to sort out which of these two micrologics is more important for the LURC correlation with formalization. Also, more work is needed on the interactions of the institutions explored in this article. Is it possible that institutions may serve as complements or substitutes? For instance, are changes in entry barriers (such as the Enterprise Law) more effective in regimes characterized by high property rights? Do policies, such as Business Development Services and transparency of regulatory documentation, substitute for poor property rights? This article has been only a first cut, but the PCI data can be an effective instrument for answering these questions as well.

Edmund Malesky is assistant professor of political science at the Graduate School of International Relations and Pacific Studies at the University of California-San Diego. He has published in leading political science and economic journals and has been awarded the Harvard Academy Fellowship and Gabriel Almond Award for best dissertation in comparative politics. Malesky serves as the lead researcher for the Vietnam Provincial Competitiveness Index 
and Cambodian Business Environment Scorecard. He has consulted for the Asia Foundation, USAID, and the World Bank Group. Markus Taussig is a doctoral candidate with the Strategy Unit at Harvard Business School focused on issues of entrepreneurial strategy and finance in emerging markets. Taussig lived in Vietnam over ten years, working with various international development organizations on implementation of enterprise surveys and auditing of SOEs. He also helped launch an international rubber trading company and managed a tourism startup for three years.

\section{Notes}

Earlier versions of this article were presented at the annual meeting of the American Political Science Association (APSA) in Boston (August 2008) and the Harvard Developmental Economics Seminar (October 2008). The article has benefited from the valuable advice of Melani Cammett, Tom Kenyon, James Anderson, Shawn Cole, Toan Do, Ngoc Anh Tran, Nguyen Van Thang, Dau Anh Tuan, Lakshmi Iyer, Josh Lerner, Kim Ninh, Steve Parker, Jim Winkler, Chris Woodruff, two anonymous reviewers, and Stephan Haggard, editor of Journal of East Asian Studies. Research assistance was provided by Lily Phan, Quinn Dang, Tran Thi Thuy Trang, and Nguyen Manh Tuan. Special thanks go to the Asia Foundation, Developmental Alternatives Incorporated, the Vietnamese Chamber of Commerce and Industry, and the United States Agency for International Development, which were responsible for the survey, and to the Vietnam Competitiveness Initiative, which supported this research and generously made the data available for our analysis.

1. For an excellent overview of the prereform history of private enterprise in Vietnam, see Dang (1999). This article serves as the primary source of information for the next two paragraphs.

2. Decree 27/ND and Decree 29 in 1988 set the legal framework for household businesses.

3. The first Enterprise Law was introduced in December 1990, setting up the framework for sole proprietorships, followed by 1991 legislation allowing registration of limited liability and joint-stock companies as well.

4. The 1999 Enterprise Law also introduced a fourth type of company: partnerships. Partnerships are the least common company form, tending to be more prevalent for services companies such as law firms and consulting companies.

5. The total number of PCI respondents has grown over time. We exploit the 2007 dataset for this analysis, which has 6,700 firms, but the most recent iteration had 7,820. More importantly, at least fifty respondents are recorded for each province, allowing for valid statistical analysis. When incorrect addresses and bankruptcies are taken into account, the response rate for the PCI is about 30 percent. This is quite high by international business survey standards, but nonresponse bias remains a possibility, as seven out of ten entrepreneurs chose not to respond. Further analysis reveals that the response bias is 
negative. More frustrated firms are more likely to respond. Fortunately, the response bias is systematic across provinces. The variance in response rates is only 5 percent, thus the negative impact on governance score applies generally across the sixty-four units. See the annual PCI reports for more detail (www.pcivietnam.org).

6. Each of the subindexes is scaled 1-10, so the final unweighted index score can be calculated by simply summing up the components. A weighted PCI is available, but it is not useful for this empirical analysis, because individual weights are based on a subindex's contribution to private sector growth and performance.

7. Data and full reports are available at www.pcivietnam.org.

8. See Online Appendix 3 (http://irps.ucsd.edu/faculty/faculty-directory/ edmund-malesky.htm) for more details.

9. The rationale for this is the substantial number of tangible changes in recent years, including another Enterprise Law and a Competition Law in 2005 , and the steadily increasing pressure for further regulatory reform-not only due to obligations laid out in the bilateral trade agreement with the United States and in the accession agreement to the World Trade Organization, but also due to market pressures as services and product markets continue to globalize at a rapid pace.

10. This closely parallels the regional groupings of provinces determined by Vietnam's GSO, though we made some small changes to better reflect true similarities in character and resources. It should be noted that GSO has changed membership in these groupings on a fairly regular basis. In some cases, provinces have been moved from a less successful grouping of provinces to a more successful grouping because of an improvement in the province's own performance.

11. While we do not have direct evidence on firms that never formalized, as noted earlier, analysis of aggregate levels of formalization in Figure 1 and Online Appendix 3 indicates that this nondecision is also highly dependent on the quality of provincial governance.

12. In this case, negative binomial is preferred to poisson regression because of high dispersion in the data.

\section{References}

Abrami, Regina M., and Nolwen Henaff. 2004. "The City and the Countryside: Economy, State and Socialist Legacies in the Vietnamese Labor Market." In Reaching for the Dream: Challenges of Sustainable Development in Vietnam, ed. Melanie Beresford and Angie Tran. Honolulu: University of Hawaii Press.

Acemoglu, Daron, and Simon Johnson. 2005. "Unbundling Institutions.” Journal of Political Economy 113, 5: 949-995. 
Aldrich, Howard, and C. Marlene Fiol. 1994. "Fools Rush In? The Institutional Context of Industry Creation." Academy of Management Review 19, 4: 645-670.

Antunes, Antonio, and Tiago Cavalcanti. 2007. "Start-Up Costs, Limited Enforcement, and the Hidden Economy." European Economic Review 51: 203-224.

Ardagna, Silvia, and Annamaria Lusardi. 2008. "Explaining International Differences in Entrepreneurship: The Role of Individual Characteristics and Regulatory Constraints.” NBER Working Paper Series 14012. Cambridge, MA: National Bureau of Economic Research.

Bennett, John, and Saul Estrin. 2007. "Entrepreneurial Entry in Developing Economies: Modeling Interactions Between the Formal and the Informal Sector." International Policy Center Working Paper Series 44. Available at http://hdl.handle.net/2027.42/55758 (accessed February 20, 2009).

Coase, Ronald. 1937. "The Nature of the Firm." Economica 4, 16: 386-405.

Dang Phong. 1999. "The Private Sector in Vietnamese Industry from 1945 to the Present." In Vietnam's Undersized Engine: A Survey of 95 Larger Private Manufacturers, ed. Leila Webster and Markus Taussig. Mekong Project Development Facility (MPDF) Private Sector Development Discussion Brief 8. Hanoi: MPDF.

De Soto, Hernando. 1989. The Other Path: The Invisible Revolution in the Third World. London: Tauris.

- 2000. The Mystery of Capital: Why Capitalism Triumphs in the West and Fails Everywhere Else. New York: Basic Books.

DiMaggio, Paul, and Walter Powell. 1991. The New Institutionalism in Organizational Analysis. Chicago: University of Chicago Press.

Di Tella, Rafael, Sebastian F. Galiani, and Ernesto S. Schargrodsky. 2007. "The Formation of Beliefs: Evidence from the Allocation of Land Titles to Squatters." Quarterly Journal of Economics 122, 1: 209-241.

Djankov, Simeon. 2008. "A Response to Is Doing Business Damaging Business?" Journal of Comparative Economics. Available at www.doing business.org/documents/Response_to_Arrunada_JCE.pdf? (accessed February 5, 2008).

Djankov, Simeon, Rafael La Porta, Florencio Lopez-De-Silanes, and Andrei Shleifer. 2002. "The Regulation of Entry," Quarterly Journal of Economics 117, 1: 1-37.

Djankov, Simeon, Yingyi Qian, Gerard Roland, and Ekaterina Zhuravskaya. 2008. "Entrepreneurship in Development: First Results from China and Russia." Manuscript.

Do, Quy-Toan, and Lakshmi Iyer. 2008. "Land Titling and Rural Transition in Vietnam." Economic Development and Cultural Change 56: 531-579.

Fforde, Adam, and Stefan de Vylder. 1996. From Plan to Market: The Economic Transition in Vietnam. Boulder: Westview Press.

Field, Erica. 2007. "Entitled to Work: Urban Tenure Security and Labor Supply in Peru." Quarterly Journal of Economics 122, 4: 1561-1602. 
Friedman, Eric, Simon Johnson, Daniel Kaufmann, and Pablo Zoido-Lobaton. 2000. "Dodging the Grabbing Hand: The Determinants of Unofficial Activity in 69 Countries." Journal of Public Economics 76, 3: 459-493.

Frye, Timothy, and Andrei Shleifer. 1997. "The Invisible Hand and the Grabbing Hand." American Economic Review 87, 2: 354-358.

Galiani, Sebastian, and Ernesto Schargrodsky. 2007. "Property Rights for the Poor: Effects of Land Titling." Business School Working Papers, Universidad Torcuato Di Tella, Buenos Aires.

Ghemawat, Pankaj. 2007. Redefining Global Strategy: Crossing Borders in a World Where Differences Still Matter. Boston: Harvard Business School Publishing Corporation.

Grief, Avner. 2006. Institutions and the Path to the Modern Economy: Lessons from Medieval Trade. Cambridge: Cambridge University Press.

Haare, Denise. 2008. "The Origins and Influence of Land Property Rights in Vietnam." Development Policy Review 26, 3: 339-363.

Ihrig, Jane, and Karine Moe. 2004. "Lurking in the Shadows: The

Informal Sector and Government Policy." Journal of Development Economics 73: 541-557.

Johnson, Simon, Daniel Kaufmann, John McMillan, and Chris Woodruff. 2000. "Why Do Firms Hide?" Journal of Public Economics 76, 3: 495-520.

Johnson, Simon, Andrei Shleifer, and Daniel Kaufmann. 1997. "The Unofficial Economy in Transition.” Brookings Papers on Economic Activity 28, 2.

Kaufmann, Daniel, Aart Kraay, and Massimo Mastruzzi. 2007. "Growth and Governance: A Reply.” Journal of Politics 69, 2: 555-562.

Kenyon, Thomas. 2007. "A Framework for Thinking About Enterprise Formalization Policies in Developing Countries." World Bank Policy Research Working Paper No. 4235. Washington, DC: World Bank. Available at http://ssrn.com/abstract=988845 (accessed February 20, 2009).

Kim, Annette. 2004. "A Market Without the 'Right' Property Rights." Economics of Transition 7, 3: 275-305.

King, Gary, Christopher J. L. Murray, Joshua A. Salomon, and Ajay Tandon. 2003. "Enhancing the Validity and Cross-Cultural Comparability of Measurement in Survey Research." American Political Science Review 97, 4: $567-584$.

King, Tomz, and Wittenberg. 2000. "Making the Most of Statistical Analyses: Improving Interpretation and Presentation." American Journal of Political Science 44, 2: 341-355.

Knack, Stephen, and Phillip Keefer. 1995. "Institutions and Economic Performance: Cross-Country Testing Using Alternative Institutional Measures." Economics and Politics 7, 3: 207-228.

Kocher, Matthew, Thomas B. Pepinsky, and Stathis N. Kalyvas. 2008. "Into the Arms of Rebels? Aerial Bombardment, Indiscriminate Violence, and Territorial Control in the Vietnam War." Manuscript. Yale University.

Kurtz, Marcus J., and Andrew Schrank. 2007. "Growth and Governance: Models, Measures, and Mechanisms.” Journal of Politics 69, 2: 538-554. 
Laeven, Luc, and Christopher Woodruff. 2007. "The Quality of the Legal System, Firm Ownership, and Firm Size." Review of Economics and Statistics 89, 4: 601-614.

La Porta, Rafael, F. López-de-Silanes, A. Shleifer, and R. Vishny. 1999. "The Quality of Government." Journal of Law, Economics and Organization 15, 1: 222-279.

Loayza, Norman, Ana Maria Oviedo, and Luis Serven. 2005. "The Impact of Regulation on Growth and Informality Cross-Country Evidence." World Bank Policy Research Working Paper No. 3623. Washington, DC: World Bank.

Malesky, Edmund. 2007. "The Vietnam Provincial Competitiveness Index: Measuring Economic Governance for Private Sector Development: 2007 Final Report." Vietnam Competitiveness Initiative Policy Paper No. 12. USAID's Vietnam Competitiveness Inititative, Hanoi.

- 2008. "Provincial Governance and Foreign Direct Investment in Vietnam." In Twenty Years of Foreign Investment in Vietnam. Ho Chi Minh City: Saigon Economic Times.

__ 2009. "Gerrymandering Vietnamese Style: The Political Geography of Economic Transition in an Authoritarian State." Journal of Politics 71, 1: $1-30$.

Malesky, Edmund, and Markus Taussig. 2008. "Where Is Credit Due? Legal Institutions, Connections, and the Efficiency of Bank Lending in Vietnam." Journal of Law, Economics, and Organization. http://jleo.oxford journals.org/cgi/reprint/ewn011 $\mathrm{v} 1$ ? $\max$ toshow $=\&$ HITS $=2 \&$ hits $=2 \&$ RESULTFORMAT $=\&$ andorexacttitle $=$ and $\&$ titleabstract $=$ vietnam $\&$ and orexacttitleabs $=$ and $\&$ andorexactfulltext $=$ and $\&$ searchid $=1 \&$ resource type=HWCIT. Accessed March 10, 2009.

Miguel, Edward, and Gerard Roland. 2006. "The Long Run Impact of Bombing Vietnam.” NBER Working Paper No. W11954. Cambridge: National Bureau of Economic Research.

Nguyen Dinh Cung, Pham Anh Tuan, Bui Van, and David Dapice. 2004. "Why Don't Northern Provinces Grow Faster?" Hanoi: Central Institute for Economic Management and United Nations Development Program.

North, Douglass. 1991. "Institutions." Journal of Economic Perspectives 5, 1: 97-112.

North, Douglass, and Barry Weingast. 1989. "Constitutions and Commitment: The Evolution of Institutional Governing Public Choice in SeventeenthCentury England.” Journal of Economic History 49, 4: 803-832.

O'Conner, Dennis. 2000. "Financial Sector Reform in China and Vietnam: A Comparative Perspective." Comparative Economic Studies 42, 4: 45-66.

Porter, Michael. 1980. Competitive Strategy: Techniques for Analyzing Industries and Competitors. New York: Simon \& Schuster.

Ravallion, Martin, and Dominique van de Walle. 2006. Does Rising Landlessness Signal Success or Failure for Vietnam's Agrarian Transition? World Bank Policy Research Working Paper No. 3871. Washington, DC: World Bank. 
Riehl, Evan. 2008. "Regional Regulations and Foreign Investment in Vietnam.” Manuscript, Washington University, St. Louis.

Santos, Felipe, and Kathleen Eisenhardt. 2006. "Constructing Markets and Organizing Boundaries: Entrepreneurial Action in Nascent Fields." Manuscript.

Schneider, Friedrich. 2005. "Shadow Economies Around the World: What Do We Really Know?" European Journal of Political Economy 21, 3: 598-642.

Seligson, Mitchell. 2006. "The Measurement and Impact of Corruption Victimization: Survey Evidence from Latin America." World Development 34, 2: 381-404.

Taussig, Markus, and Pham Thi Thu Hang. 2004. "Private Enterprise Formality and the Role of Local Government: Making Markets Work Better for the Poor." Asian Development Bank Discussion Paper No. 2. Hanoi: Asian Development Bank.

Tran, Thi Bich, R. Quentin Grafton, and Tom Kompas. 2008. "Institutions Matter: The Case of Vietnam." International and Development Economics Working Paper No. 08-01. Australian National University, Canberra.

Turley, William, and Brantly Womack. 1998. "Asia's Socialism's Open Doors: Guangzhou and Ho Chi Minh City." The China Journal 40: 95-119.

VCCI (Vietnam Chamber of Commerce and Industry). 2008. Vietnam Business 2008. Hanoi: VCCI.

Vietbao.vn. 2006. "Ho kinh doanh ca the chua muon chuyen thanh DN." March 22.

2007. "Ho kinh doanh ca the gop 13\% GDP." October 14.

Vijverberg, Wim. 2006. "Non-Farm Household Enterprises in Vietnam," World Bank Research Working Paper. Washington, DC: World Bank.

Vu Thanh Tu Anh, Le Viet Thai, and Vo Tat Thang. 2007. "Provincial Extralegal Investment Incentives in the Context of Decentralisation in Viet Nam: Mutually Beneficial or a Race to the Bottom?" United Nations Development Program Vietnam Working Paper Series. Hanoi: UNDP.

Webster, Leila, and Markus Taussig, eds. 1999. Vietnam's Undersized Engine: A Survey of 95 Larger Private Manufacturers. MPDF Private Sector Development Discussion Brief 8. Hanoi: MPDF.

Weingast, Barry. 1993. "Constitutions as Governance Structures: The Political Foundations of Secure Markets.” Journal of Institutional and Theoretical Economics 146, 1: 286-311.

Woodruff, Christopher. 2006. "Measuring Institutions." In International Handbook on the Economics of Corruption, ed. Susan Rose-Ackerman. Cheltenham, UK: Edward Elgar Publishing Ltd.

World Bank. 2002. Vietnam Development Report 2002: Implementing Reforms for Faster Growth and Poverty Reduction. Hanoi: World Bank. 